Research Paper

\title{
ABCB1 and ABCC11 confer resistance to eribulin in breast cancer cell lines
}

\author{
Takaaki Oba ${ }^{1}$, Hiroto Izumi ${ }^{2}$, Ken-ichi Ito ${ }^{1}$ \\ ${ }^{1}$ Division of Breast, Endocrine and Respiratory Surgery, Department of Surgery (II), Shinshu University School of Medicine, \\ Matsumoto, Japan \\ ${ }^{2}$ Department of Occupational Pneumology, Institute of Industrial Ecological Sciences, University of Occupational and \\ Environmental Health, Kitakyushu, Japan
}

Correspondence to: Ken-ichi Ito, email: kenito@shinshu-u.ac.jp

Keywords: eribulin, drug resistance, breast cancer, $A B C B 1, A B C C 11$

Received: May 13, 2016

Accepted: August 09, 2016

Published: August 31, 2016

\section{ABSTRACT}

This study aimed to elucidate the mechanisms underlying the resistance of breast cancer to eribulin. Seven eribulin-resistant breast cancer cell lines (MCF7/E, BT474/E, ZR75-1/E, SKBR3/E, MDA-MB-231/E, Hs578T/E, and MDA-MB-157/E) were established. mRNA and protein expression of ATP-binding cassette subfamily B member 1 (ABCB1) and subfamily $C$ member 11 (ABCC11) increased in all eribulin-resistant cell lines compared to the parental cell lines. When ABCB1 or ABCC11 expression was inhibited by small interfering RNA in MCF7/E, BT474/E, and MDA-MB-231/E cells, eribulin sensitivity was partially restored. Moreover, eribulin resistance was attenuated additively by inhibiting $A B C B 1$ and $A B C C 11$ in MCF7/E cells. Additionally, overexpression of exogenous ABCB1 or ABCC11 in HEK293T cells conferred resistance to eribulin. MCF7/E and MDAMB-231/E cells showed cross-resistance to paclitaxel, doxorubicin, and fluorouracil. Inhibition of ABCB1 partially restored paclitaxel and doxorubicin sensitivity. Partial restoration of fluorouracil sensitivity was induced by inhibiting ABCC11 in MCF7/E and MDA-MB-231/E cells. Both ABCB1 and ABCC11 are involved in the development of eribulin resistance in breast cancer cells in vitro regardless of the breast cancer subtype. Thus, ABCB1 and ABCC11 expression may be used as a biomarker for predicting the response to eribulin in patients with breast cancer. Concomitant inhibition of ABCB1 and ABCC11 might help enhance the antitumor effects of eribulin.

\section{INTRODUCTION}

Eribulin mesylate (eribulin) is a synthetic macrocyclic ketone analog of the marine sponge natural product halichondrin $\mathrm{B}$ and is an inhibitor of microtubule dynamics $[1,2]$. Eribulin inhibits microtubule polymerization by a mechanism distinct from those of other antitubulin agents such as vinblastine or taxanes. When administered to patients with metastatic breast cancer who had previously received both an anthracyclin and a taxane in either the adjuvant or metastatic setting, eribulin significantly increased their overall survival by monotherapy; thus, eribulin is currently an approved treatment for patients with advanced breast cancer [3]. However, most patients fail to respond to eribulin within several months, a phenomenon that has also been observed for many other cytotoxic drugs that were previously administered for breast cancer, and the mechanisms underlying this resistance to eribulin have not been fully elucidated.

ATP-binding cassette (ABC) transporters are primary active transporters that confer drug resistance by effluxing anticancer agents [4]. ABC transporters consist of 48 members that are classified into seven subfamilies from $\mathrm{ABCA}$ to $\mathrm{ABCG}$ based on their sequence similarity [5]. Among them, ABC subfamily B member 1 (ABCB1)/Pglycoprotein $(M D R 1)$ has been implicated as the major efflux transporter responsible for the resistance of cancer cells to many anticancer agents such as cisplatin, docetaxel, anthracyclines (doxorubicin, epirubicin), etoposide, irinotecan, methotrexate, paclitaxel, and vincristine $[5,6]$. Members of the $\mathrm{ABC}$ subfamily $\mathrm{C} /$ multidrug resistance protein (ABCC/MRP) superfamily consist of 13 subfamily members ( $\mathrm{ABCC} 1$ to $\mathrm{ABCC} 13)$. Among the $\mathrm{ABCC}$ subfamily members, $\mathrm{ABCC} 1$ (MRP1) and $\mathrm{ABCC} 2$ (MRP2) 
are known to have transport mechanisms for a wide variety of chemotherapeutic agents; they also confer resistance to various anticancer agents including anthracyclines, etoposide, methotrexate, mitoxantrone, and cisplatin [5, 7-13], whereas ABCC11 confers resistance to fluorouracil, methotrexate, and pemetrexed [14-21]. However, the involvement of $\mathrm{ABC}$ transporters in the resistance of cancer cells to eribulin has not yet been reported.

To elucidate the mechanisms underlying the development of eribulin resistance in breast cancer cells, we established several eribulin-resistant cell lines using different breast cancer cell subtypes. In the present study, we demonstrated for the first time that $\mathrm{ABCB} 1$ and ABCC11 confer eribulin resistance in breast cancer cells regardless of their subtype.

\section{RESULTS}

\section{Establishment of eribulin-resistant breast cancer cell lines}

Eribulin-resistant breast cancer cell lines were obtained by culturing MCF7, BT474, ZR75-1, SKBR3, MDA-MB-231, Hs578T, and MDA-MB-157 cells with stepwise increases in the eribulin concentration for more than
6 months. The eribulin-resistant cell lines were designated as MCF7/E, BT474/E, ZR75-1/E, SKBR3/E, MDA-MB231/E, Hs578T/E, and MDA-MB-157/E, respectively. The relative eribulin resistance of each eribulin-resistant cell line compared to the corresponding parental cell line was determined using a WST assay (Figure 1). Although an eribulin-resistant cell line was established for each breast cancer cell line, the $\mathrm{IC}_{50}$ for the eribulin-resistant cell lines varied among the cell lines. The $\mathrm{IC}_{50}$ for the parental cell lines ranged from 0.1 to $1.3 \mathrm{nM}$, whereas the $\mathrm{IC}_{50}$ for the eribulin-resistant cell lines ranged from 4.7 to $556.7 \mathrm{nM}$. The eribulin resistance of the eribulin-resistant cell lines was 7.9-fold to 672.1-fold greater than that of the parental cell lines. The MCF7/E cell line showed the highest $\mathrm{IC}_{50}(556.7$ $\pm 108.4 \mathrm{nM})$, whereas the SKBR3/E cell line showed the lowest $\mathrm{IC}_{50}(4.7 \pm 0.4 \mathrm{nM})$.

The expression of estrogen receptor $\alpha(\mathrm{ER} \alpha)$ and human epidermal growth factor receptor-2 (HER2) in each parental cell line was evaluated by western blotting. Expression of ER $\alpha$ was detected in MCF7, BT474, and ZR75-1 cells. Expression of HER-2 was detected in BT474 and SKBR3 cells (Supplementary Figure 1). The characteristics of the parental cell lines and $\mathrm{IC}_{50}$ for eribulin in the parental and eribulin-resistant cell lines are summarized in Table 1.
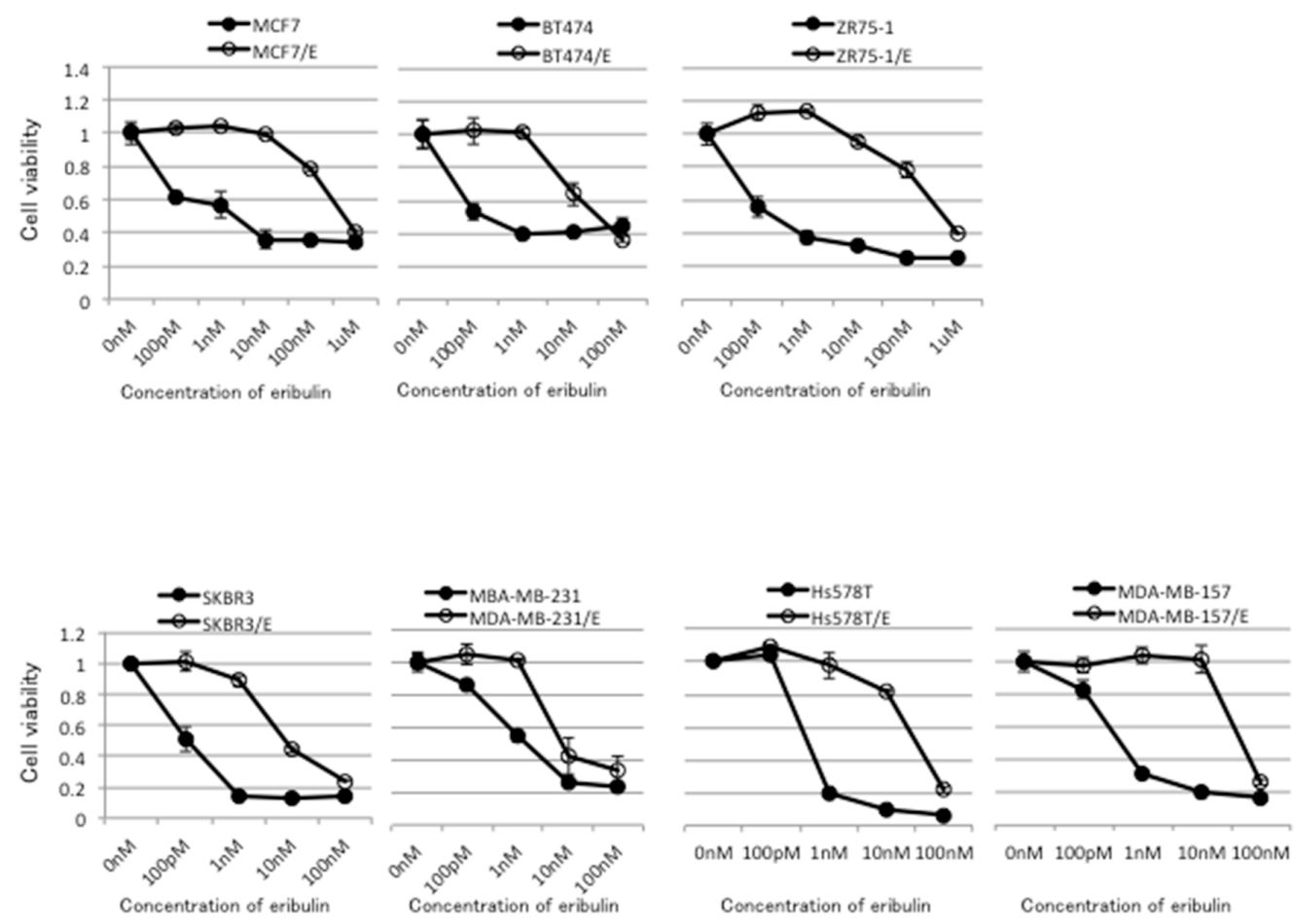

Figure 1: Sensitivity to eribulin in eribulin-resistant breast cancer cells and their parental cells. Eribulin-resistant breast cancer cell lines were obtained by culturing MCF7, BT474, ZR75-1, SKBR3, MDA-MB-231, Hs578T, and MDA-MB-157 cells with stepwise-increasing doses of eribulin for more than 6 months. Sensitivity to eribulin was assayed by using the WST assay. Each cell line with "/E" indicates an established eribulin-resistant cell line. Closed circles $(\bullet)$ indicate parental cells, whereas open circles $(\circ)$ indicate eribulin-resistant cells. The error bars represent the standard error of the value obtained in the experiments performed in triplicate. 
Table 1: Characteristics and $\mathrm{IC}_{50}$ for eribulin in the parental and eribulin-resistant breast cancer cell lines

\begin{tabular}{|c|c|c|c|c|c|c|c|c|c|c|c|c|c|c|}
\hline Cell line & \multicolumn{2}{|c|}{ MCF7 } & \multicolumn{2}{|c|}{ BT474 } & \multicolumn{2}{|c|}{ ZR75-1 } & \multicolumn{2}{|c|}{ SKBR3 } & \multicolumn{2}{|c|}{$\begin{array}{l}\text { MDA- } \\
\text { MB-231 }\end{array}$} & \multicolumn{2}{|c|}{ Hs578T } & \multicolumn{2}{|c|}{$\begin{array}{c}\text { MDA- } \\
\text { MB-157 }\end{array}$} \\
\hline $\mathrm{ER} \alpha$ & \multicolumn{2}{|c|}{+} & \multicolumn{2}{|c|}{+} & \multicolumn{2}{|c|}{+} & \multicolumn{2}{|c|}{-} & \multicolumn{2}{|c|}{-} & \multicolumn{2}{|c|}{-} & \multicolumn{2}{|c|}{-} \\
\hline HER2 & \multicolumn{2}{|c|}{ - } & \multicolumn{2}{|c|}{+} & \multicolumn{2}{|c|}{-} & \multicolumn{2}{|c|}{+} & \multicolumn{2}{|c|}{-} & \multicolumn{2}{|c|}{-} & \multicolumn{2}{|c|}{-} \\
\hline $\begin{array}{l}\text { Parental or } \\
\text { eribulin- } \\
\text { resistant }\end{array}$ & $\mathrm{P}$ & $\mathrm{E}$ & $\mathrm{P}$ & $\mathrm{E}$ & $\mathrm{P}$ & E & $\mathrm{P}$ & $\mathrm{E}$ & $\mathrm{P}$ & E & $\mathrm{P}$ & $\mathrm{E}$ & $\mathrm{P}$ & $\mathrm{E}$ \\
\hline $\begin{array}{l}\mathrm{IC}_{50}(\mathrm{nM}) \\
(\text { mean } \pm \mathrm{SD})\end{array}$ & $\begin{array}{c}1.3 \pm \\
0.5\end{array}$ & $\begin{array}{c}556.7 \\
\pm \\
108.4\end{array}$ & $\begin{array}{c}0.6 \pm \\
0.1\end{array}$ & $\begin{array}{l}20.8 \\
\pm 8.8\end{array}$ & $\begin{array}{c}0.6 \pm \\
0.1\end{array}$ & $\begin{array}{c}403.3 \\
\pm \\
32.9\end{array}$ & $\begin{array}{c}0.1 \pm \\
0.1\end{array}$ & $\begin{array}{c}4.7 \pm \\
0.4\end{array}$ & $\begin{array}{c}1.1 \pm \\
0.1\end{array}$ & $\begin{array}{c}8.7 \pm \\
1.4\end{array}$ & $\begin{array}{c}0.7 \pm \\
0.0\end{array}$ & $\begin{array}{r}26.2 \\
\pm 1.2\end{array}$ & $\begin{array}{c}0.6 \pm \\
0.0\end{array}$ & $\begin{array}{l}56.7 \\
\pm 9.4\end{array}$ \\
\hline $\begin{array}{l}\text { Relative } \\
\text { resistance } \\
\text { ratio }^{\text {a }}\end{array}$ & & 428.2 & & 34.6 & & 672.1 & & 47.0 & & 7.9 & & 37.7 & & 94.5 \\
\hline
\end{tabular}

P: parental cell, E: eribulin-resistant cell, $\mathrm{IC}_{50}$ : half-maximal inhibitory concentration, ER $\alpha$ :estrogen receptor- $\alpha$, HER2: human epidermal growth factor receptor type 2 .

${ }^{a}$ Relative resistance ratio $=\mathrm{IC}_{50}$ of eribulin-resistant cells $/ \mathrm{IC}_{50}$ of parental cells.

\section{Increased expression of $\mathrm{ABCB} 1$ and $\mathrm{ABCC} 11$ in eribulin-resistant breast cancer cell lines}

Prior to the present study, we compared the gene expression profile between MCF7 and MCF7/E cells by microarray analysis. The expression of $\mathrm{ABCB} 1$ and ABCC11 in MCF7/E cells increased 56.1-fold and 19.7fold, respectively, compared to that in the parental MCF7 cells (data not shown). Based on this result, we examined the expression of $\mathrm{ABCB} 1$ and $\mathrm{ABCC} 11$ in seven breast cancer cell lines and their eribulin-resistant cells by realtime RT-PCR and western blotting. Figure 2A and 2B show the ABCB1 mRNA expression levels quantitated by real-time RT-PCR and the representative western blots of $\mathrm{ABCB} 1$, respectively, for the parental and eribulinresistant cell lines. Although the expression levels varied from cell line to cell line, ABCB1 mRNA expression was significantly increased in all eribulin-resistant cell lines compared to the expression in the corresponding parental cell lines. In BT474/E, ZR75-1/E, and MDMB-157/E cells, a significant increase in ABCB1 expression was observed in both the real-time RT-PCR and western blot analyses, whereas the increased $\mathrm{ABCB} 1$ expression that was detected by real-time RT-PCR did not correspond to the results of the western blot analyses in the $\mathrm{MCF} 7 / \mathrm{E}$ and SKBR3/E cells.

Figure 2C and 2D show the ABCC11 mRNA expression levels quantitated by real-time RT-PCR and representative western blots of $\mathrm{ABCC} 11$, respectively, for the parental and eribulin-resistant cell lines. Realtime RT-PCR revealed that expression of ABCC11 was significantly increased in all eribulin-resistant cell lines compared to the expression in the corresponding parental cell lines; moreover, the increases in $\mathrm{ABCC} 11$ expression that were detected by western blot analyses were similar to the expression increases observed in the real-time RTPCR analyses. Hence, upregulation of both ABCB1 and ABCC11 in breast cancer cells was induced by continuous treatment regardless of the subtype of the cells.

\section{Restoration of eribulin sensitivity by $\mathrm{ABCB} 1$ or ABCC11 knockdown in eribulin-resistant breast cancer cells}

To further examine the involvement of ABCB1 and $\mathrm{ABCC} 11$ in the development of eribulin resistance in breast cancer cells, we tested whether knockdown of $\mathrm{ABCB} 1$ or $\mathrm{ABCC} 11$ would restore eribulin sensitivity in eribulin-resistant breast cancer cells. We chose three eribulin-resistant cell lines (MCF7/E, BT474/E, and MDA-MB-231/E) for the experiment. Inhibition of ABCB1 expression by small interfering RNA (siRNA) was confirmed at both the mRNA and protein levels for the three cell lines (Figure 3A). Eribulin sensitivity was partially restored in MCF7/E and BT474/E cells, whereas siRNA targeting of $\mathrm{ABCB} 1$ resensitized the MDA-MB$231 / \mathrm{E}$ cells to eribulin to the same $\mathrm{IC}_{50}$ level as the parental MDA-MB-231 cells (Figure 3B).

Inhibition of ABCC11 expression by siRNA was confirmed at both the mRNA and protein levels in the three cell lines (Figure 3C). Eribulin sensitivity was partially restored in the three selected eribulin-resistant cell lines. The restoration effect was more potent in MCF7/E cells than in the other cells (Figure 3D). The growth inhibitory effects induced by eribulin in the eribulin-resistant cell lines in these experiments were of lower magnitude than the effects demonstrated in Figure 1, and this discrepancies was considered to result from the shorter incubation times 
A
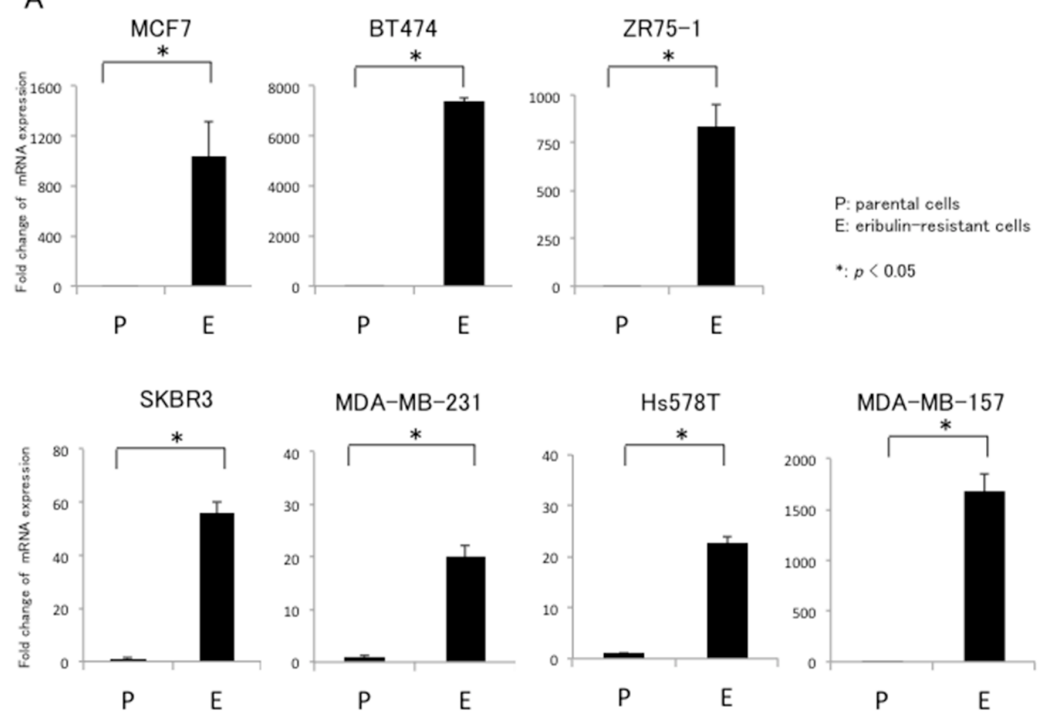

B

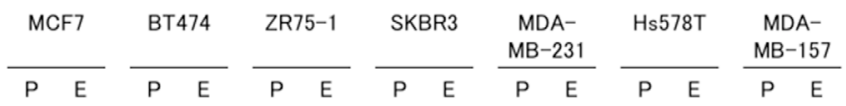
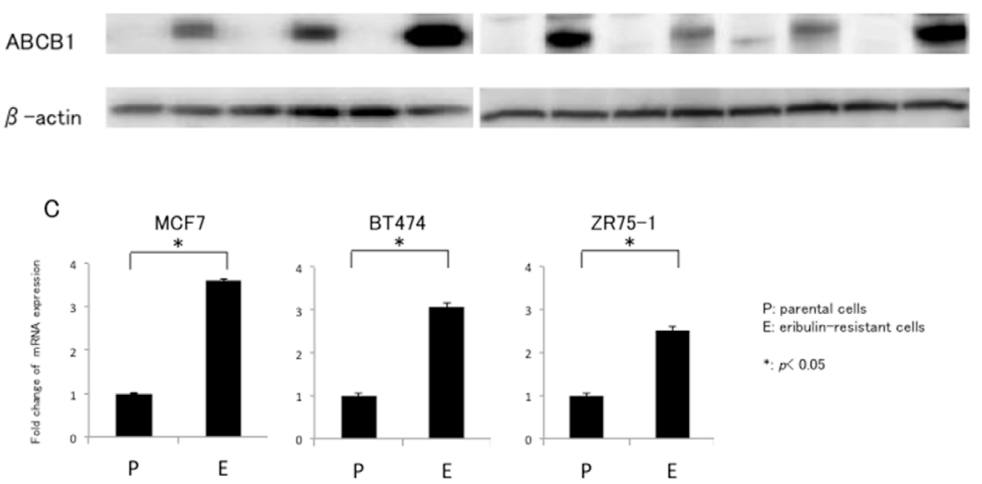

P: parental cells
E: eribulin-resistant cells

$\because p<0.05$
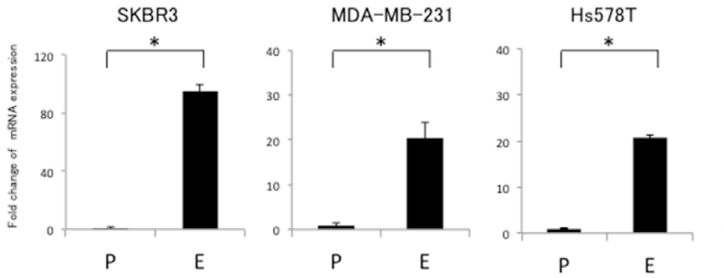

MDA-MB-157

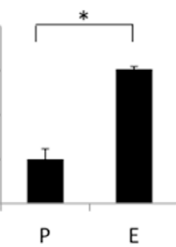

D
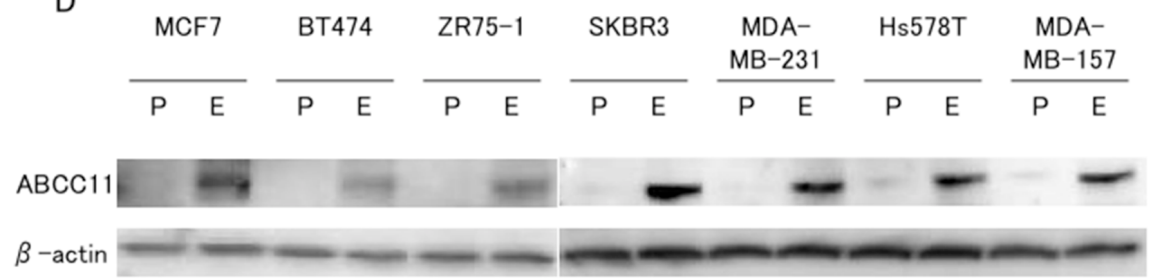

Figure 2: mRNA and protein expression of $\mathrm{ABCB} 1$ and $\mathrm{ABCC} 11$ in eribulin-resistant breast cancer cells and their parental cells. A. ABCB1 mRNA expression quantitated by real-time RT-PCR. $\beta$-actin was used as an internal control. "P" indicates parental cell line and "E" indicates eribulin-resistant cell line. The error bars represent the standard error of the value obtained in the experiments performed in triplicate. B. ABCB1 protein expression analyzed with western blotting. $\beta$-actin was used as a loading control. C. ABCC11 mRNA expression quantitated by real-time RT-PCR. D. ABCC11 protein expression analyzed by western blotting. $* P<0.05$ for parental cell line vs. eriburin-resistant cell line. 

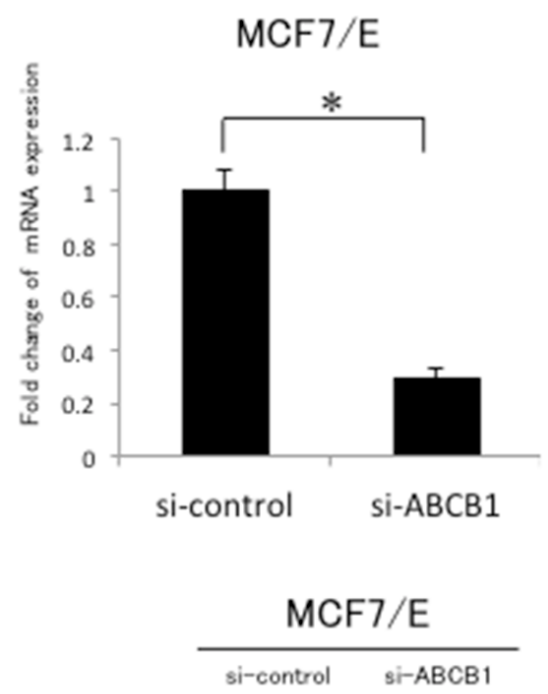

ABCB1

$\beta-$ actin
BT474/E
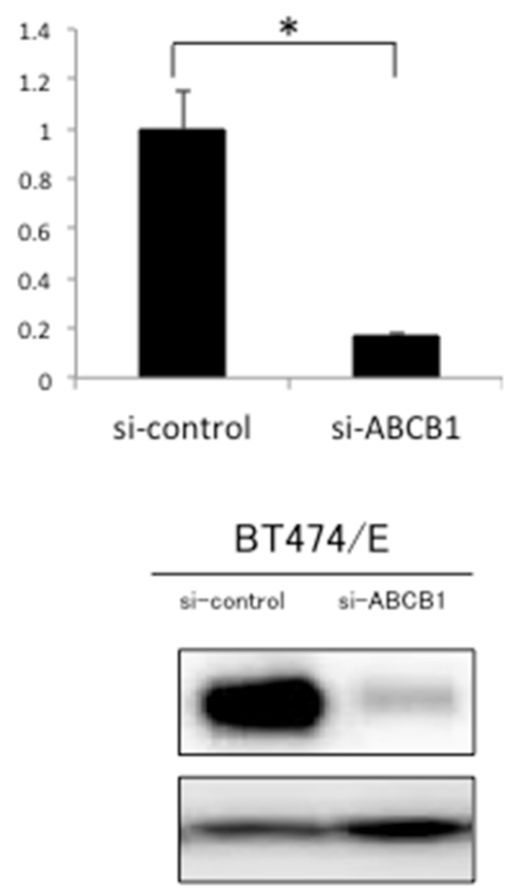

MDA-MB-231/E
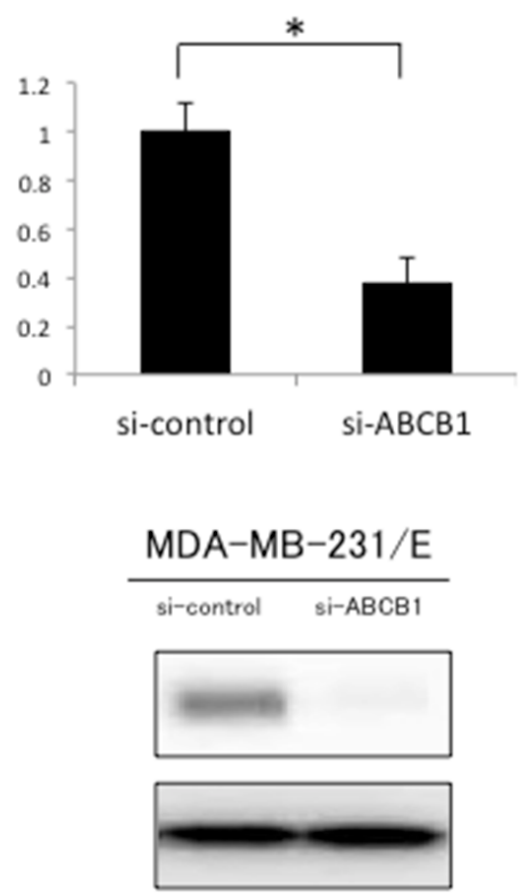

B

$\mathrm{MCF} 7 / \mathrm{E}$
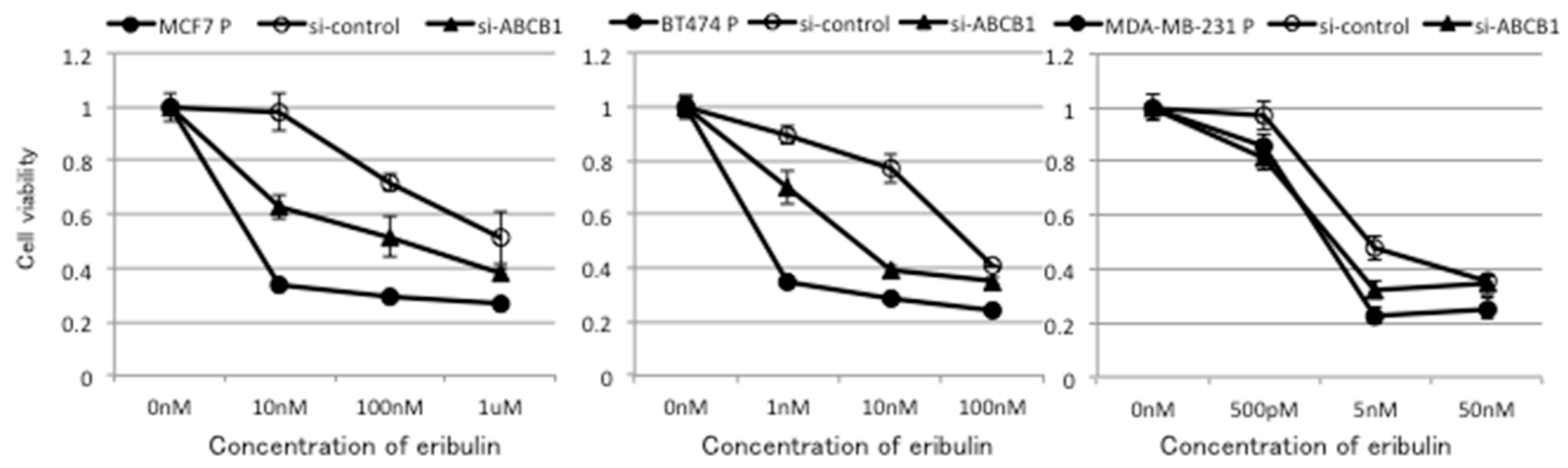

Figure 3: Effects of $\mathrm{ABCB} 1$ or $\mathrm{ABCC} 11$ knockdown in eribulin-resistant breast cancer cells. The expression of $\mathrm{ABCB} 1$ and ABCC11 in MCF7/E, BT474/E, and MDA-MB231/E cells was inhibited by siRNA, and the sensitivity to eribulin was tested using WST assays. A. ABCB1 mRNA expression quantitated by real-time RT-PCR (upper panel) and representative results of western blot analyses (lower panel) in MCF7/E, BT474/E, and MDA-MB-231/E cells transfected with siRNA targeting ABCB1 (si-ABCB1) or control siRNA (si-control). ${ }^{*} P<0.05$ for si-control vs. si-ABCB1. $\beta$-actin was used as a loading control. The error bars represent the standard error of the value obtained in the experiments performed in triplicate. B. Sensitivity to eribulin was measured in eribulin-resistant cells transfected with siRNA (si-control or si-ABCB1) and the parental cells. Closed circles $(\bullet)$ indicate parental cells, whereas open circles $(\circ)$ indicate eribulinresistant cells transfected with si-control; closed triangles $(\mathbf{\Delta})$ indicate eribulin-resistant cells transfected with si-ABCB1, respectively.

(Continued) 

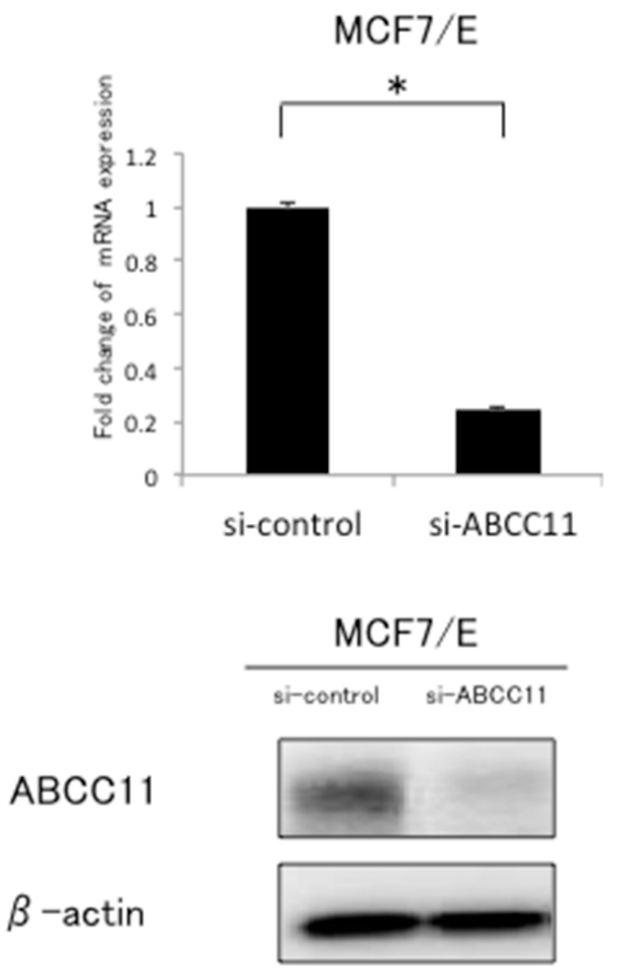

BT474/E
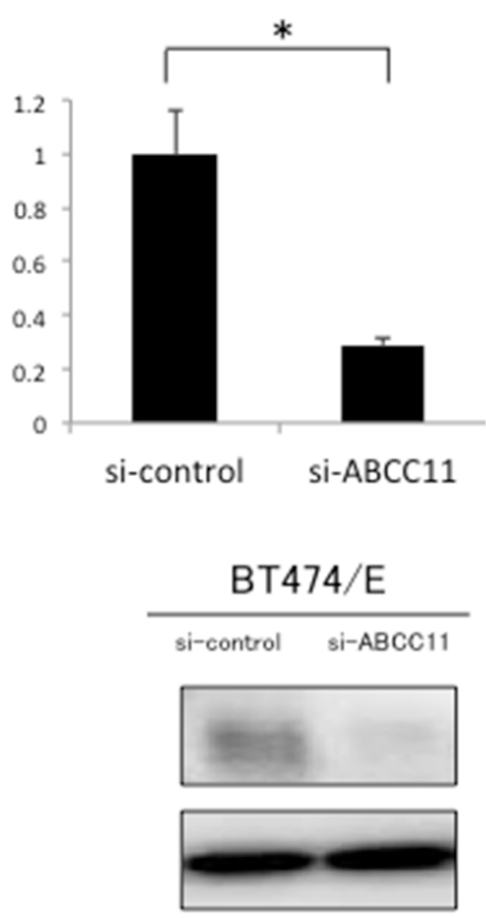

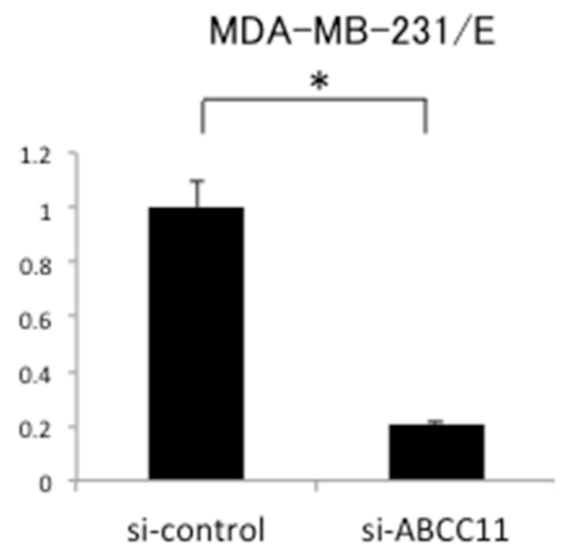

D

MCF7/E

BT474/E

$\frac{M D A-M B-231 / E}{\text { si-control }}$
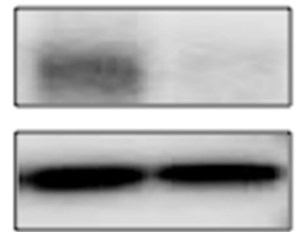

D

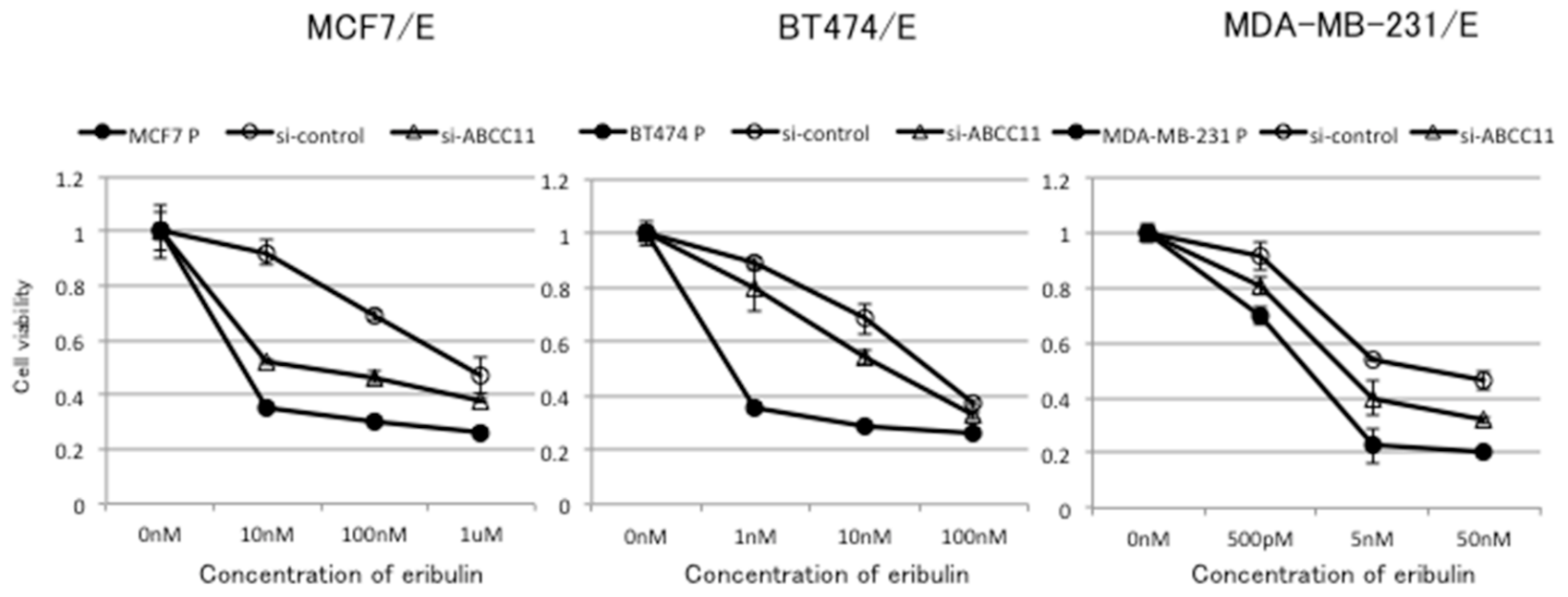

Figure 3 (Continued): C. ABCC11 mRNA expression quantitated by real-time RT-PCR (upper panel) and representative results of the western blot analyses (lower panel) in MCF7/E, BT474/E, and MDA-MB-231/E cells transfected with siRNA targeting ABCC11 (si$\mathrm{ABCC} 11$ ) or control siRNA (si-control). ${ }^{*} P<0.05$ for si-control vs. si-ABCC11. $\beta$-actin was used as a loading control. D. Sensitivity to eribulin was measured in eribulin-resistant cells transfected with siRNA (si-control or si-ABCC11) and the parental cells. Closed circles ( $\bullet$ ) indicate parental cells, open circles (O) indicate eribulin-resistant cells transfected with si-control, and open triangles (D) indicate eribulinresistant cells transfected with si-ABCC11.

(Continued) 


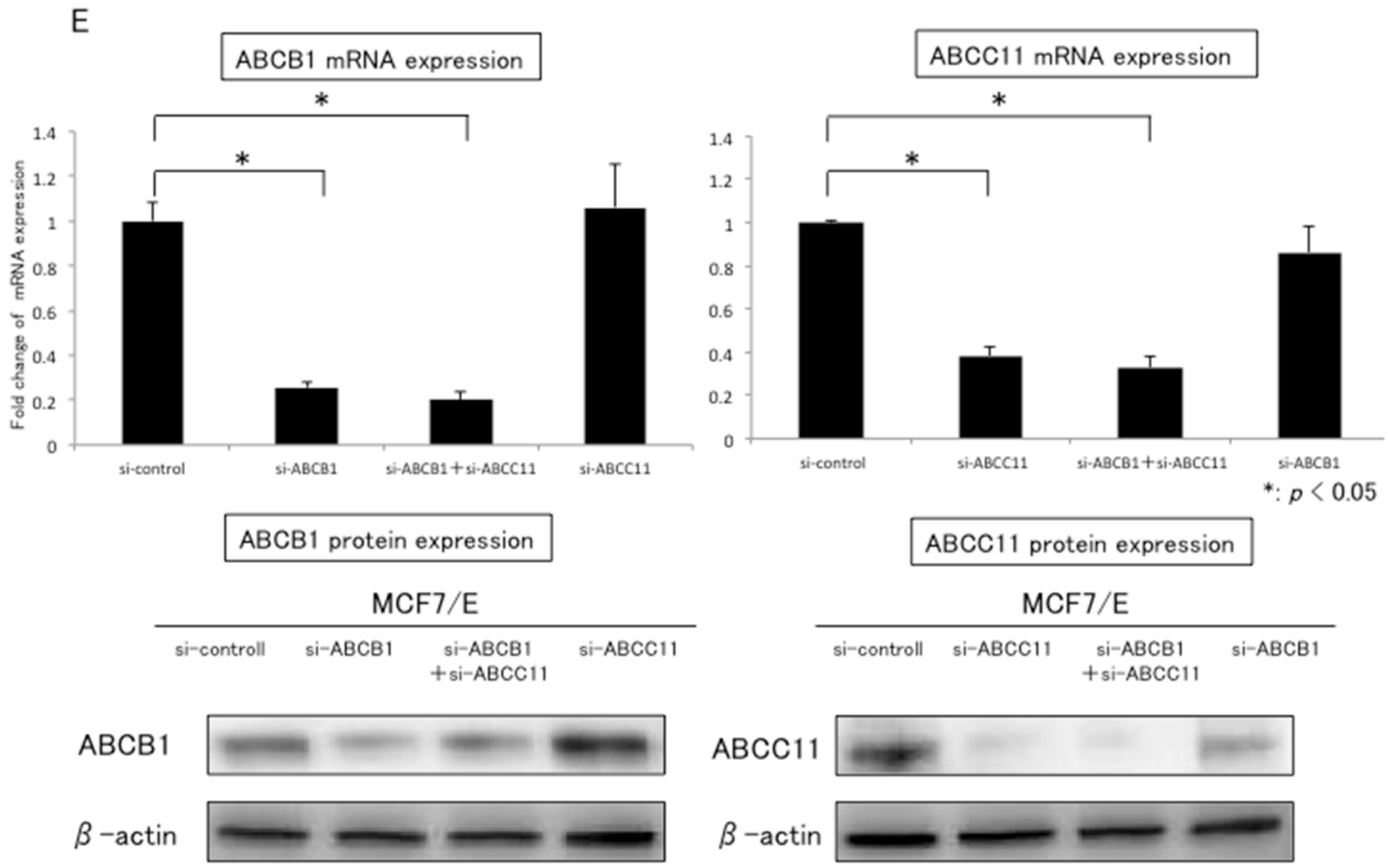

Sensitivity to eribulin

$\mathrm{F}$

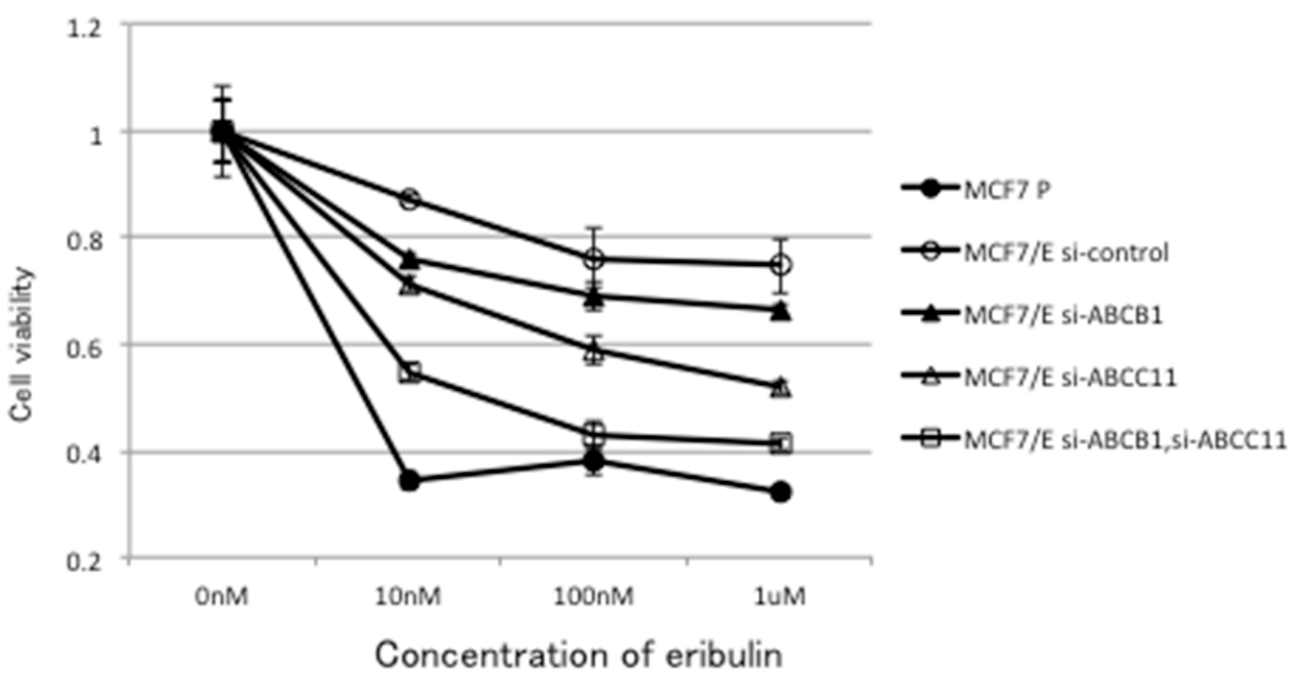

Figure 3 (Continued): E. ABCB1 and ABCC11 mRNA expression quantitated by real-time RT-PCR (upper panel) and representative results of the western blot analyses (lower panel) in MCF7/E cells transfected with siRNA targeting ABCB1 (si-ABCB1), ABCC11 (si$\mathrm{ABCC} 11$ ), both $\mathrm{ABCB} 1$ and $\mathrm{ABCC} 11$ (si-ABCB1 + si-ABCC11), or control siRNA (si-control). $* P<0.05$. F. Sensitivity to eribulin was measured in the parental MCF7 cells and eribulin-resistant MCF7/E cells transfected with each siRNA. Closed circles $(\bullet)$ indicate parental MCF7 cells, open circles (O) indicate MCF7/E cells transfected with si-control, closed triangles $(\triangle)$ indicate MCF7/E cells transfected with si-ABCB1, open triangles $(\triangle)$ indicate MCF7/E cells transfected with si-ABCC11, and open squares $(\square)$ indicate MCF7/E cells transfected with both si-ABCB1 and si-ABCC11. The error bars represent the standard error of the value obtained in the experiments performed in triplicate. 
in the siRNA experiments compared with the experiments used to determine the $\mathrm{IC}_{50}$ for each cell line.

Next, to evaluate whether the sensitivity to eribulin was restored additively by inhibiting expression of both $\mathrm{ABCB} 1$ and $\mathrm{ABCC} 11$ in the eribulin-resistant MCF7/E cells, knockdown of both $\mathrm{ABCB} 1$ and $\mathrm{ABCC} 11$ was performed in the MCF7/E cells. When the MCF7/E cells were transfected with siRNA that targeted $\mathrm{ABCB} 1$ and siRNA that targeted ABCC11, the expression of both $\mathrm{ABCB} 1$ and $\mathrm{ABCC} 11$ was inhibited to the same extent as when the cells were transfected with either siRNA alone. Expression of ABCB1 was not inhibited by transfection with the ABCC11-targeting siRNA, and expression of ABCC11 was not inhibited by transfection with the ABCB1-targeting siRNA (Figure 3E). Inhibition of both $\mathrm{ABCB} 1$ and $\mathrm{ABCC} 11$ expression in the MCF7/E cells restored eribulin sensitivity to approximately the level observed for the parental MCF7 cells (Figure 3F). These results demonstrate that inhibiting the expression of either $\mathrm{ABCB} 1$ or $\mathrm{ABCC} 11$ restored the sensitivity to eribulin, although the degree of restoration varied depending on the cell line, indicating that $\mathrm{ABCB} 1$ and $\mathrm{ABCC} 11$ are involved in the development of eribulin resistance in these breast cancer cells.

\section{Overexpression of either $\mathrm{ABCB} 1$ or $\mathrm{ABCC} 11$ confers resistance to eribulin in SV40- transformed human embryonic kidney (HEK293T) cells}

To confirm that both ABCB1 and ABCC11 were able to confer resistance to eribulin in breast cancer cells, we tested whether transient overexpression of $\mathrm{ABCB} 1$ or $\mathrm{ABCC} 11$ would alter the sensitivity to eribulin in HEK293T cells. A plasmid containing FlagABCB1 or Flag-ABCC11 was introduced into HEK293T cells. HEK293T cells transfected with an empty vector (pcDNA3.1) were used as a control. In the HEK293T cells transfected with the empty vector, no ABCB1 expression was detected in western blots, whereas weak expression of ABCC11 was detected. Thus, neither ABCB1 nor ABCC11 was expressed at a high level in HEK293T cells. In contrast, high expression of $\mathrm{ABCB} 1$ and $\mathrm{ABCC} 11$ was detected in HEK293T cells that were transfected with the vectors expressing $\mathrm{ABCB} 1$ or $\mathrm{ABCC} 11$. The production of $\mathrm{ABCB} 1$ and $\mathrm{ABCC} 11$ by exogenously introduced genes was confirmed by immunoblots with an anti-FLAG antibody (Figure 4A).

In the HEK293T cells that were transfected with an empty vector, the $\mathrm{IC}_{50}$ for eribulin was $2.8 \mathrm{nM}$, whereas in the HEK293T cells that were transfected with ABCB1, the $\mathrm{IC}_{50}$ for eribulin was $833.3 \mathrm{nM}$, indicated a 297.6-fold in resistance compared to the cells transfected with the empty vector. In the cells that were transfected with $\mathrm{ABCC} 11$, the $\mathrm{IC}_{50}$ for eribulin was $9.1 \mathrm{nM}$, which indicated a 3.3-fold increase in resistance compared to the cells transfected with the empty vector. Thus, exogenous overexpression of both $\mathrm{ABCB} 1$ and $\mathrm{ABCC} 11$ was able to confer resistance to eribulin in HEK293T cells, although the degree of resistance induced by $\mathrm{ABCB} 1$ was more remarkable than that induced by ABCC11 (Figure 4B).

Furthermore, HEK293T cells that were transfected with ABCB1 became resistant to paclitaxel and doxorubicin, whereas HEK293T cells that were transfected with $\mathrm{ABCC} 11$ became resistant to fluorouracil (Figure 4C-4E). However, transfection of HEK293T cells with $\mathrm{ABCC} 11$ did not confer resistance to either paclitaxel or doxorubicin, whereas transfection of HEK293T cells with $\mathrm{ABCB} 1$ did not alter their sensitivity to fluorouracil (Figure 4C-4E).

\section{Cross-resistance to paclitaxel, doxorubicin, and fluorouracil in eribulin-resistant breast cancer cells}

$\mathrm{ABCB} 1$ is known to confer resistance to a variety of anticancer agents including paclitaxel and doxorubicin [5]. ABCC11 is associated with resistance to fluorouracil [18]. In our experiments, overexpression of ABCB1 conferred resistance to doxorubicin, paclitaxel, and eribulin in HEK293T cells, whereas overexpression of ABCC11 conferred resistance to both fluorouracil and eribulin. Given these findings, we examined whether MCF7/E and MDA-MB231/E breast cancer cells would demonstrate cross-resistance to paclitaxel, doxorubicin, and fluorouracil. As demonstrated in Figure 5A, both MCF7/E and MDA-MB-231/E cells showed higher $\mathrm{IC}_{50}$ for paclitaxel, doxorubicin, and fluorouracil compared to their parental cell lines, indicating that both cell lines acquired cross-resistance to these three drugs in the course of developing resistance to eribulin (Figure 5 and Table 2).

\section{Inhibition of $\mathrm{ABCB} 1$ or $\mathrm{ABCC} 11$ alters the cross-resistance to paclitaxel, doxorubicin, and fluorouracil in eribulin-resistant breast cancer cells}

To further investigate the involvement of $\mathrm{ABCB} 1$ and $\mathrm{ABCC} 11$ in the observed cross-resistance to paclitaxel, doxorubicin, and fluorouracil in MCF7/E and MDA-MB231/E cells, we inhibited ABCB1 or ABCC11 expression with siRNA in these cells and evaluated the sensitivity to paclitaxel, doxorubicin, and fluorouracil (Figure 6). Both the mRNA and protein expression of $\mathrm{ABCB} 1$ and $\mathrm{ABCC} 11$ was decreased at $24 \mathrm{~h}$ after transfection with siRNA that targeted $\mathrm{ABCB} 1$ or $\mathrm{ABCC} 11$, respectively (Supplementary Figure 2). Inhibition of ABCB1 expression partially restored the sensitivity to paclitaxel and doxorubicin in both MCF7/E and MDA-MB-231/E cells (Figure 6A and $6 \mathrm{~B}$ ). Inhibition of $\mathrm{ABCB} 1$ expression did not alter the sensitivity to fluorouracil in either cell type (Figure $6 \mathrm{C})$. In contrast, partial restoration of the sensitivity to 
A

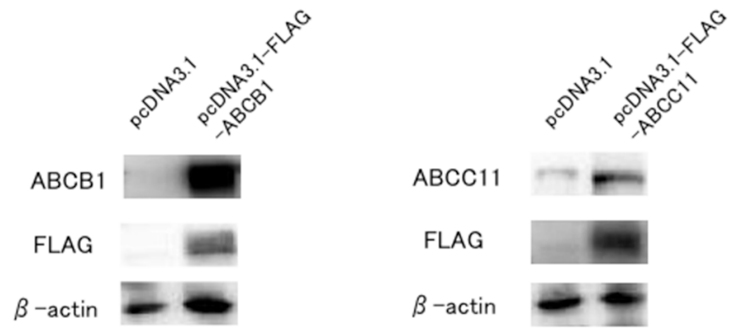

B

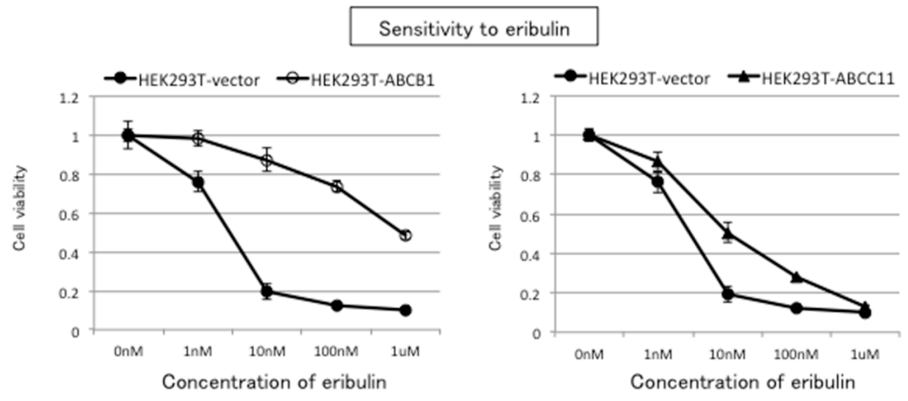

C

Sensitivity to paclitaxel
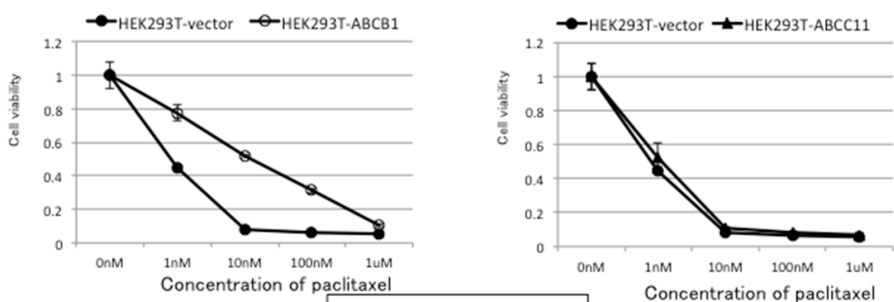

D

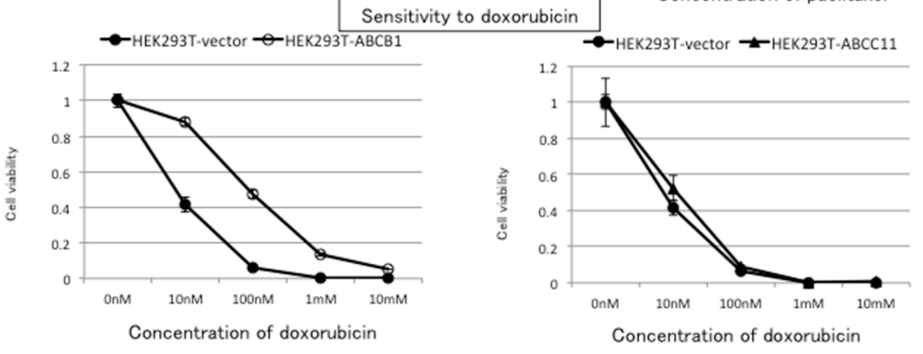

$\mathrm{E}$

Sensitivity to fluorouracil

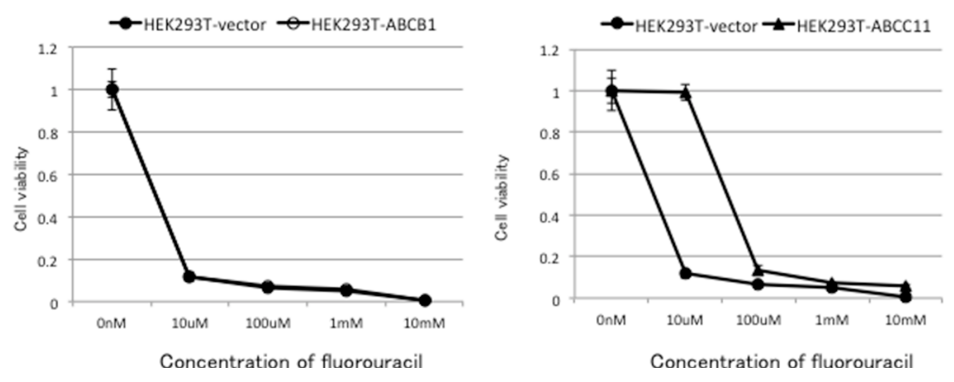

Figure 4: Effects of ABCB1 or ABCC11 overexpression on the sensitivity of HEK293T cells to eribulin, paclitaxel, doxorubicin, and fluorouracil. A plasmid expressing Flag-ABCB1 (pcDNA3.1-FLAG-ABCB1) or Flag-ABCC11 (pcDNA3.1FLAG-ABCC11) or an empty vector (pcDNA3.1) was transfected into HEK293T cells, and we tested whether overexpression of ABCB1 or ABCC11 altered the sensitivity to eribulin, paclitaxel, doxorubicin, and fluorouracil in the transiently transfected HEK293T cells. A. $\mathrm{ABCB} 1$ and $\mathrm{ABCC} 11$ protein expression in HEK-293T cells transfected with the plasmid DNA $24 \mathrm{~h}$ after transfection. Exogenously expressed $\mathrm{ABCB} 1$ and $\mathrm{ABCC} 11$ were detected by the specific antibodies for ABCB1 and ABCC11, and also the anti-FLAG antibody. The sensitivity to eribulin B. paclitaxel C. doxorubicin D. and fluorouracil E. in HEK293T cells transfected with the empty vector (HEK293Tvector) or the expression vectors for ABCB1 (HEK293T-ABCB1) or ABCC11 (HEK293T-ABCC11) was determined $72 \mathrm{~h}$ after transfection. Closed circles $(\bullet)$ indicate HEK293T-vector, open circles (O) indicate HEK293T-ABCB1, and closed triangles ( $\boldsymbol{\Delta})$ indicate HEK293T$\mathrm{ABCC} 11$. The error bars represent the standard error of the value obtained in the experiments performed in triplicate. 
A
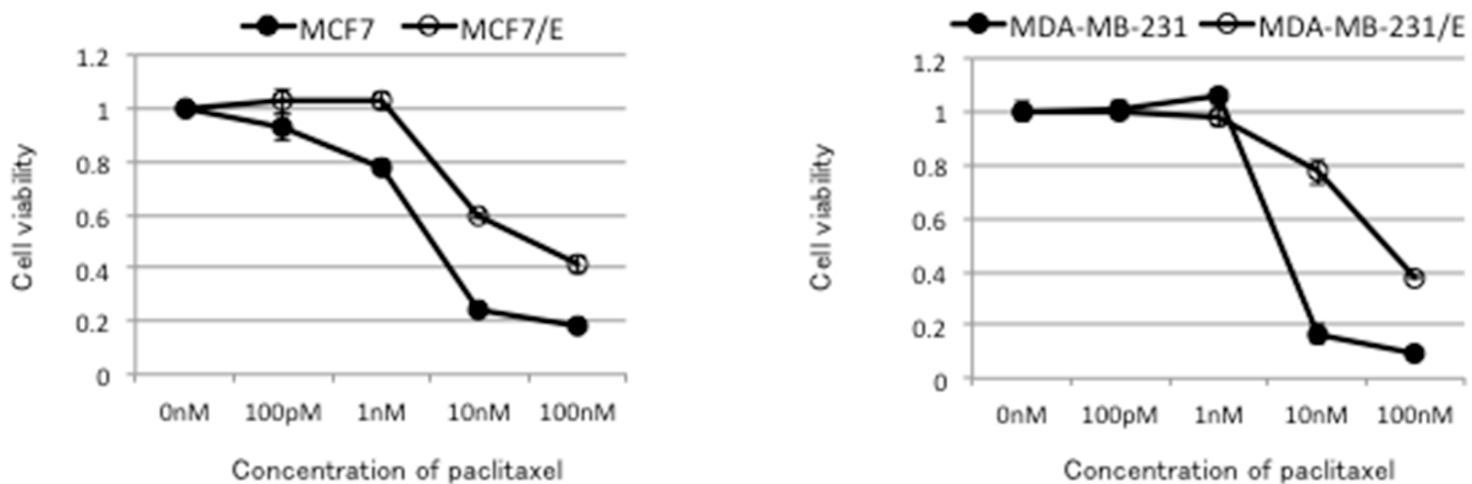

Sensitivity to doxorubicin

$\mathrm{B}$

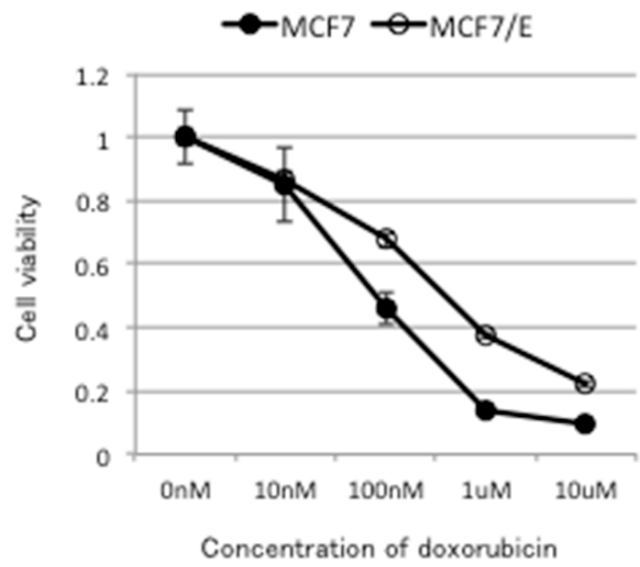

MDA-MB-231 -MDA-MB-231/E

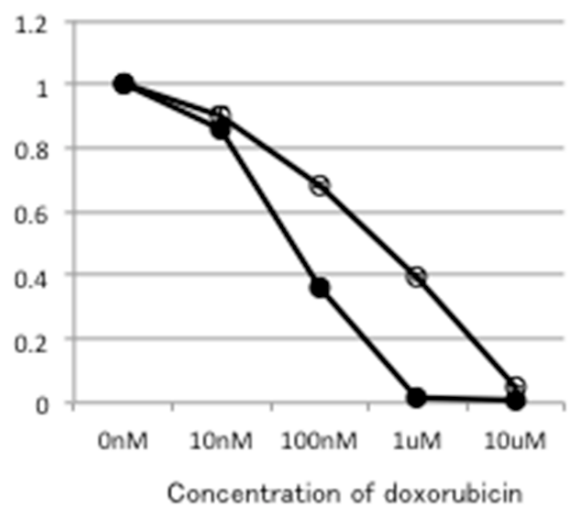

C

\section{Sensitivity to fluorouracil}
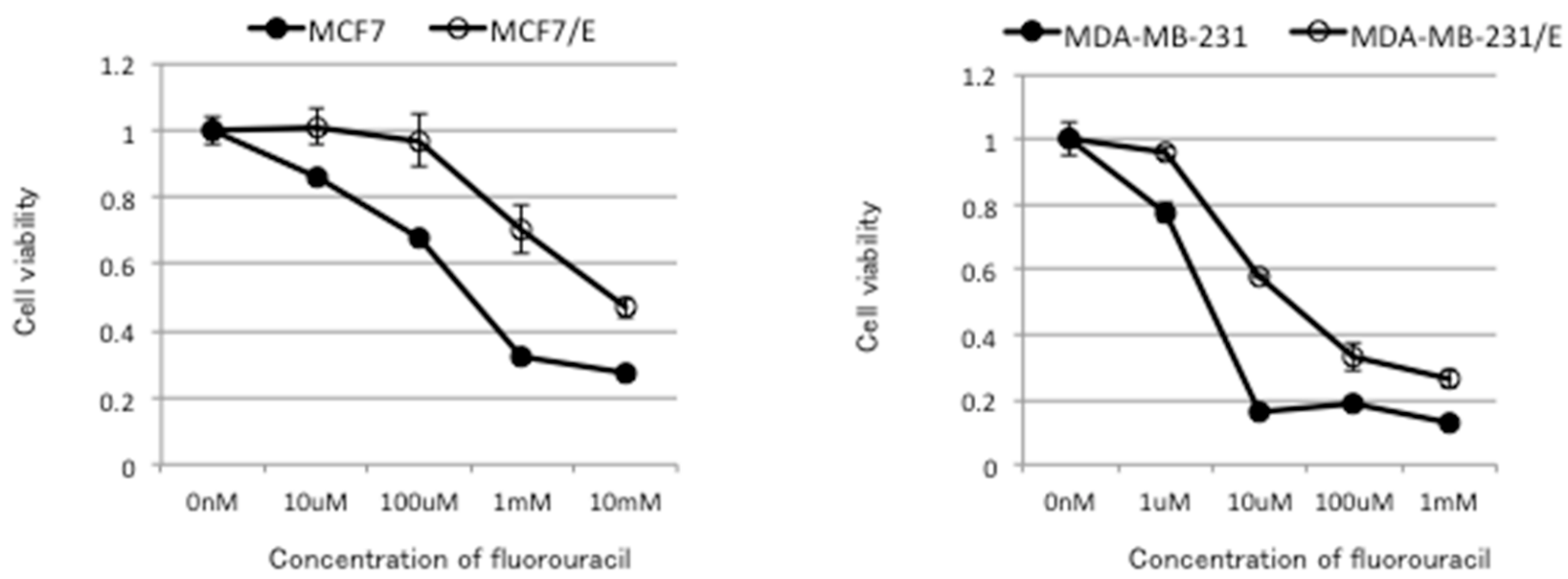

Figure 5: Cross-resistance to paclitaxel, doxorubicin, and fluorouracil in eribulin-resistant breast cancer cells. Sensitivity to paclitaxel A. doxorubicin B. and fluorouracil C. in eribulin-resistant and parental MCF7 and MDA-MB231 cells was determined by WST assay. Closed circles $(\bullet)$ indicate parental cells, whereas open circles ( $(\circ)$ indicate eribulin-resistant cells. The error bars represent the standard error of the value obtained in experiments performed in triplicate. 
Table 2: $\mathrm{IC}_{50}$ for paclitaxel, doxorubicin, and fluorouracil in parental/eribulin-resistant MCF7 and MDA-MB-231 cells

\begin{tabular}{lcccccc}
\hline & MCF7 & MCF7/E & RR & MDA-MB231 & MDA-MB231/E & RR \\
\hline Paclitaxel & $2.1 \pm 0.3 \mathrm{nM}$ & $29.3 \pm 8.7 \mathrm{nM}$ & 13.9 & $4.1 \pm 0.3 \mathrm{nM}$ & $50.3 \pm 2.9 \mathrm{nM}$ & 12.3 \\
Doxorubicin & $79.3 \pm 7.4 \mathrm{nM}$ & $376.7 \pm 30.9 \mathrm{nM}$ & 4.8 & $50.3 \pm 1.7 \mathrm{nM}$ & $453.3 \pm 32.9 \mathrm{nM}$ & 9.0 \\
Fluorouracil & $306.7 \pm 40.1 \mu \mathrm{M}$ & $4833.3 \pm 154.5 \mu \mathrm{M}$ & 15.7 & $2.9 \pm 0.3 \mu \mathrm{M}$ & $18.7 \pm 0.5 \mu \mathrm{M}$ & 6.4 \\
\hline
\end{tabular}

$\mathrm{RR}$ : relative resistance ratio $=\mathrm{IC}_{50}$ of eribulin-resistant cells $/ \mathrm{IC}_{50}$ of parental cells.

A
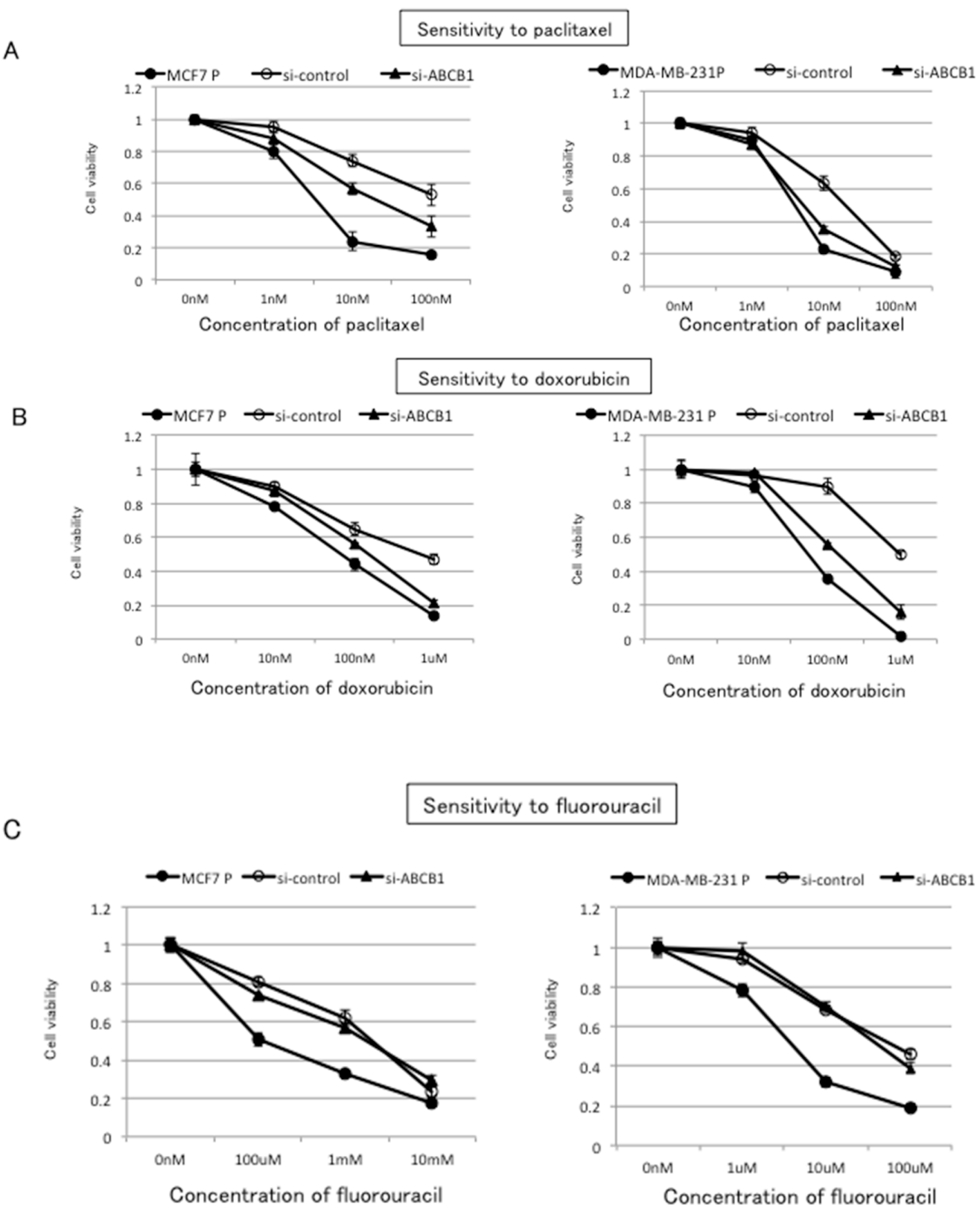

Figure 6 (Continued): Effects of $\mathrm{ABCB} 1$ and $\mathrm{ABCC} 11$ knockdown on cross-resistance to paclitaxel, doxorubicin, and fluorouracil in eribulin-resistant breast cancer cells. The expression of ABCB1 and ABCC11 in MCF7/E and MDA-MB231/E cells was inhibited by siRNA, and the sensitivity to paclitaxel, doxorubicin, and fluorouracil was tested by WST assay. Sensitivity to paclitaxel A. doxorubicin B. and fluorouracil C. in eribulin-resistant cells transfected with si-ABCB1 or si-control and the parental cells.

(Continued) 
D

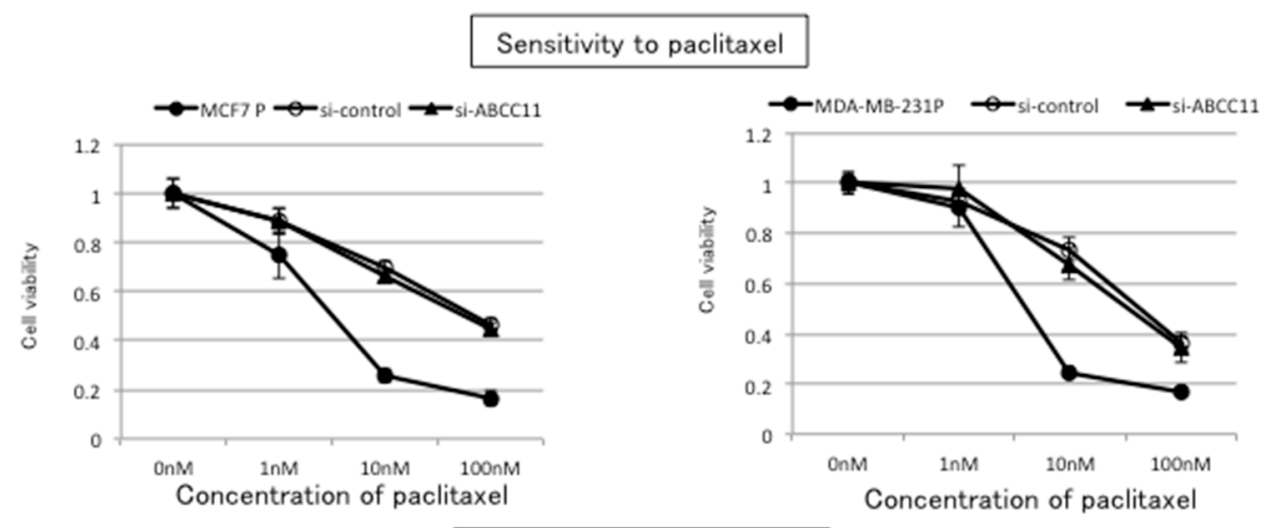

$\mathrm{E}$

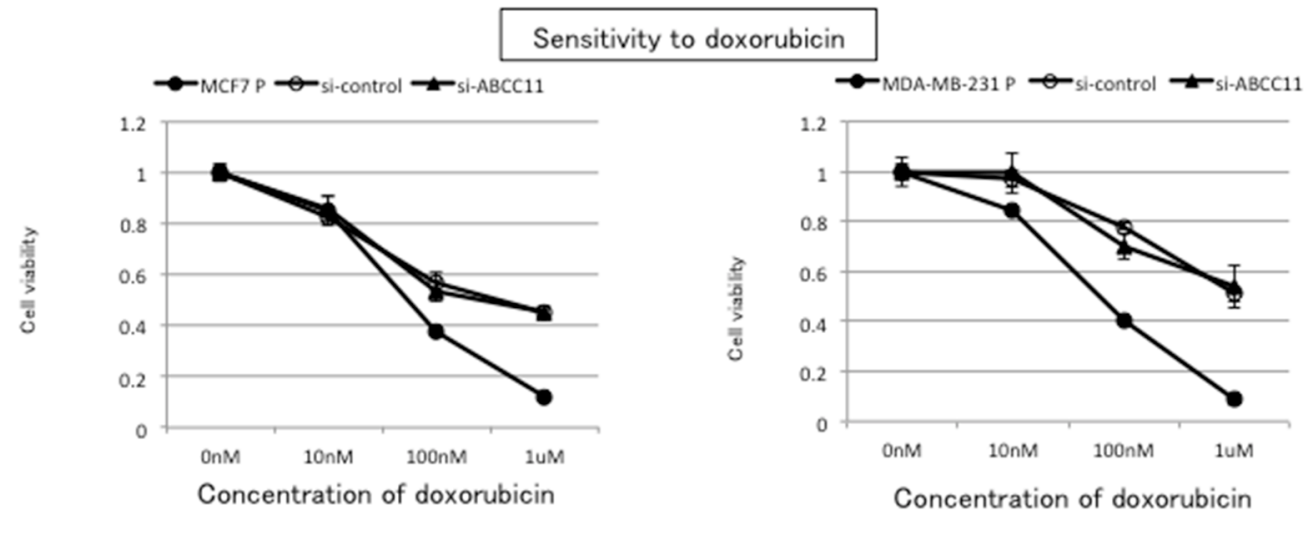

$\mathrm{F}$

Sensitivity to fluorouracil
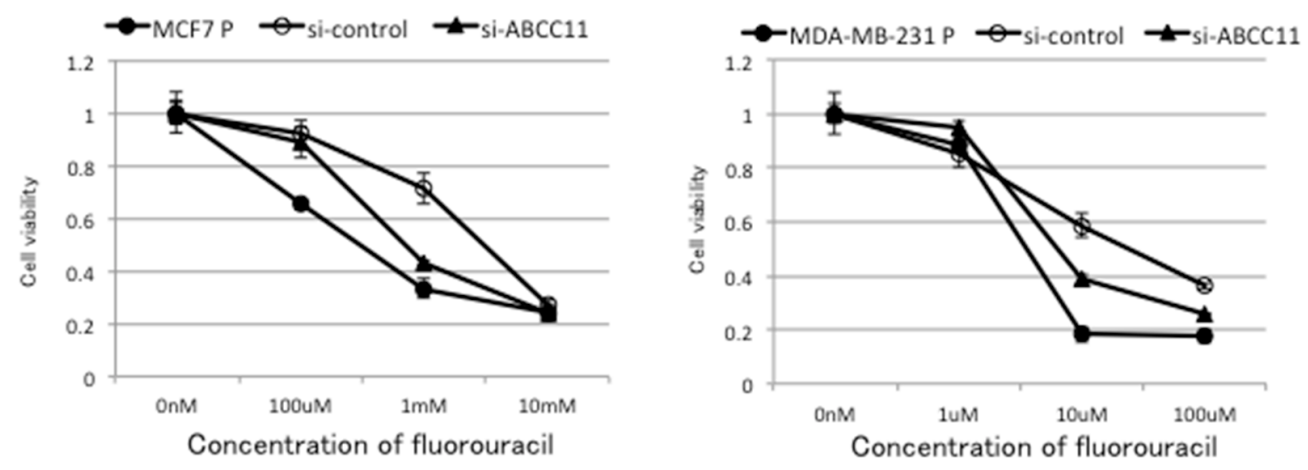

Sensitivity to paclitaxel.Figure 6 (Continued): D. doxorubicin E. and fluorouracil F. in eribulin-resistant cells transfected with siABCC11 or si-control and the parental cells. Closed circles $(\bullet)$ indicate parental cells, open circles $(\circ)$ indicate eribulin-resistant cells transfected with si-control, and closed triangles $(\boldsymbol{\Delta})$ indicate eribulin-resistant cells transfected with si-ABCB1 (A, B, and C) or with si-ABCC11 (D, E, and F), respectively.

fluorouracil was on inhibition of ABCC11 expression in MCF7/E and MDA-MB231/E cells, whereas inhibition of $\mathrm{ABCC} 11$ expression did not alter the sensitivity of either cell type to paclitaxel and doxorubicin (Figure 6D-6F). These results indicate that the cross-resistance to paclitaxel and doxorubicin that was observed in the MCF7/E and MDA-MB-231/E cells was mainly derived from ABCB1, whereas the cross-resistance to fluorouracil was mainly derived from $\mathrm{ABCC} 11$.

\section{DISCUSSION}

Thus far, the mechanisms underlying resistance to eribulin have remained unknown. In the present study, we demonstrated that the expression of two $\mathrm{ABC}$ transporters, $\mathrm{ABCB} 1$ and $\mathrm{ABCC} 11$, which belong to different $\mathrm{ABC}$ transporter subfamilies, was increased in eribulin-resistant breast cancer cell lines. Furthermore, overexpression of $\mathrm{ABCB} 1$ and $\mathrm{ABCC} 11$ conferred resistance to eribulin independently in HEK293T cells. To the best of our 
knowledge, this is the first report to demonstrate the involvement of ABCC11 in the development of eribulin resistance in cancer cells. Although Laughney et al. [22] also reported an association between $\mathrm{ABCB} 1$ and eribulin resistance, our study is the first to show that resistance to eribulin can be directly induced by transfecting cells with the $A B C B 1$ gene in vitro. Our data suggest that both $\mathrm{ABCB} 1$ and $\mathrm{ABCC} 11$ are involved in the development of eribulin resistance in breast cancer cells and that eribulin or its metabolites might be substrates of $\mathrm{ABCB} 1$ and ABCC11.

$\mathrm{ABC}$ transporters play biologically important roles as membrane transporters [4]. In addition to their many physiological functions in the normal cells of various organs, some transporters have been known to induce resistance to anticancer agents by effluxing the agents themselves or their metabolites from cancer cells [23]. ABCB1 was identified in 1976 by Juliano and Ling [24] as a membrane glycoprotein that is overexpressed in colchicine-resistant cell lines and reduces drug permeability. ABCB1 has a wide substrate spectrum and can therefore mediate the export of a variety of drugs from different drug classes. These substrates include chemotherapeutic drugs such as anthracyclines, taxanes, and vinca alkaloids $[6,25-30]$.

In contrast, the classification of the $\mathrm{ABCC}$ subfamily originated from the finding of multidrug resistance protein-1 (MRP1) as the second major ABC drug transporter by Cole et al. in 1992 [13]. Three research groups cloned $\mathrm{ABCC} 11$, a member of the ABCC subfamily, independently in 2001 [15, 16, 20]. Subsequent studies demonstrated that a nonsynonymous single nucleotide polymorphism $(538 \mathrm{G}>\mathrm{A})$ in the $A B C C 11$ gene determines the type of human earwax and axillary osmidrosis [31-33]. Additionally, it has been reported that human ABCC11 functions as an ATP-dependent efflux pump for amphipathic anions, including cyclic nucleotides, leukotriene $\mathrm{C} 4$, estrone 3-sulfate, estradiol 17-beta-D-glucuronide, and anti-viral agents [14, 19, $21,34,35]$. Guo et al. [14] demonstrated that pig kidney epithelial cells transfected with wild-type ABCC11 exhibited increased resistance to fluorouracil, whereas increased resistance was not detected for vincristine, paclitaxel, doxorubicin, or etoposide. In lung cancer cell lines, $\mathrm{ABCC} 11$ has been reported to confer resistance to fluorouracil, methotrexate, and pemetrexed [14-21].

In our study, resistance to fluorouracil was induced by overexpression ABCC11 in HEK293T cells, whereas the sensitivity to paclitaxel or doxorubicin was not altered. Moreover, the sensitivity to fluorouracil was enhanced by inhibition of $\mathrm{ABCC} 11$ expression with siRNA in MCF7/E cells that demonstrated increased ABCC11 expression and cross-resistance to fluorouracil. Thus, our findings, together with the results of previous studies, demonstrate that $\mathrm{ABCC} 11$ is involved in the alteration of fluorouracil sensitivity in cancer cells. However, no previous studies reported an association between $\mathrm{ABCC} 11$ and resistance to eribulin. In the present study, increased ABCC11 expression was detected in all of the eribulin-resistant clones established by exposing seven different breast cancer cell lines to eribulin. In addition, exogenous expression of ABCC11 decreased the sensitivity to eribulin in HEK293T cells. Thus, it is clear that ABCC11 is involved in altering eribulin sensitivity in cancer cells. Although many molecules are likely involved in the development of eribulin resistance in clinical breast cancers, our report is the first to concretely reveal some of the mechanisms underlying eribulin resistance.

A meta-analysis of 31 studies previously demonstrated that ABCB1 (MDR1/P-glycoprotein) expression in tumors is associated with a poor response to chemotherapy [9-36]. Although the strategy to interfere with the transport activity of ABCB1 (MDR1/ P-glycoprotein) has not been applied successfully in a clinical setting, accumulated data obtained from both in vitro and clinical samples indicate that ABCB1 (MDR1/ P-glycoprotein) serves an important role in determining phenotype, including the susceptibility of breast cancer cells to anticancer agents [5, 6, 29, 36-38]. Ota et al. [39] reported an association between a single nucleotide polymorphism $(538 \mathrm{G}>\mathrm{A})$ in $\mathrm{ABCC} 11$ and the risk of breast cancer in Japanese women. In addition, Yamada et al. [40] recently reported that $\mathrm{ABCC} 11$ was expressed significantly more frequently in aggressive subtypes and was associated with a poor prognosis in patients with breast cancer. These findings indicate a certain role of $\mathrm{ABCC} 11$ in the development and progression of breast cancer. It is intriguing that the expression of two ABC transporters with different substrate specificity was increased simultaneously by long-term exposure to eribulin in seven breast cancer cell lines, regardless of the receptor status of the cell lines. Eribulin binds to the vinca domain of tubulin; however, its antimitotic mechanism is distinct from that of other microtubule inhibitors such as vinca alkaloids and taxanes. Although the mechanisms underlying the transcriptional regulation of $A B C C 11$ have not been elucidated, a common transcriptional regulatory mechanism might exist for up-regulation of the $A B C B 1$ and $A B C C 11$ genes induced by eribulin-mediated stress.

The biology of breast cancer is known to depend largely on its subtype, which is determined mainly by the receptor status, and it is globally accepted that the therapeutic strategy is based on the subtype [41]. In the present study, upregulation of both ABCB1 and ABCC11 was observed in all seven breast cancer cell lines, regardless of their receptor status. These findings highlight the universal involvement of these transporters in the development of eribulin resistance in breast cancer cells. However, the degree to which ABCC11 contributed to eribulin resistance was much higher in MCF7 cells, which are positive for $\mathrm{ER} \alpha$, than in the triple-negative breast cancer cell lines. Thus, the degree to which each 
transporter contributes to eribulin resistance may vary among breast cancer subtypes. Honorat et al. [42] reported a positive correlation between $\mathrm{ABCC} 11$ and $\mathrm{ER} \alpha$ in breast cancer cell lines and clinical specimens, and indicated a possible contribution of ABCC11 to the sensitivity to chemotherapeutic agents including fluorouracil in ER $\alpha$ positive breast cancer that is resistant to tamoxifen. In the present study, the increased ABCC11 expression induced by the long-term exposure to eribulin conferred resistance to fluorouracil in ER-positive MCF7 cells. Therefore, our data strongly support that ABCC11 is involved in the development of fluorouracil resistance in ER-positive breast cancer cells.

Recently, Shi et al. demonstrated that ER $\alpha$ activates $A B C B 1$ transcription and increases paclitaxel resistance in ER $\alpha$-positive breast cancer cells [43]. Their report together with the study of Honorat et al. described above suggests that $\mathrm{ER} \alpha$ is involved in the regulation of both $\mathrm{ABCB} 1$ and $\mathrm{ABCC} 11$ expression in ER $\alpha$-positive breast cancer cells, although these transporters were upregulated in breast cancer cells regardless of the expression of $\mathrm{ER} \alpha$ in the present study. Therefore, further studies are required to elucidate the transcriptional regulation of these transporters in both ER $\alpha$-positive and ER $\alpha$-negative breast cancer cells.

Many anticancer agents have been applied in the treatment of breast cancer, and the prognoses of patients with recurrent or metastatic breast cancer have improved [44]. However, multidrug resistance induced by previously administered anticancer agents is frequently encountered in clinical practice and often limits the efficacy of subsequent anticancer agents. In the present study, both MCF7/E and MDA-MB231/E cells showed crossresistance to three key drugs that are used to treat breast cancer, namely doxorubin, paclitaxel, and fluorouracil. Furthermore, the involvement of ABCB1 and ABCC11 in the cross-resistance was confirmed by siRNA-mediated knockdown. Although further examination is necessary to determine whether or not eribulin increases ABCB1 and ABCC11 expression in clinically treated breast cancer, the induction of resistance to key breast cancer treatment drugs should be taken into consideration when designing a treatment strategy for patients with recurrent breast cancer.

In conclusion, our study demonstrated that both $\mathrm{ABCB} 1$ and $\mathrm{ABCC} 11$ were able to confer resistance to eribulin; we also showed that increased expression of both $\mathrm{ABCB} 1$ and $\mathrm{ABCC} 11$ may be involved in the development of eribulin resistance in breast cancer cells, regardless of the subtype. Our results suggest that $\mathrm{ABCB} 1$ and $\mathrm{ABCC} 11$ may be used as biomarkers for predicting the response to eribulin in patients with breast cancer. Moreover, a novel therapeutic strategy for enhancing or prolonging the therapeutic effects of eribulin might be established by revealing the precise mechanisms underlying the induction of these transporters or by designing a specific inhibitor for them.

\section{MATERIALS AND METHODS}

\section{Cell culture and agents}

Seven breast cancer cell lines (MCF7, BT474, ZR75-1, SKBR3, MDA-MB-231, Hs578T, and MDAMB-157) were purchased from the American Type Cell Collection (Manassas, VA) at the beginning of the study. HEK293T cells were kindly donated by Dr. Takeshita Toshikazu at Shinshu University. All cell lines were cultured in RPMI with $10 \% \mathrm{FBS}$ at $37.0^{\circ} \mathrm{C}$ under $5 \%$ $\mathrm{CO}_{2}$. Eribulin-resistant cell lines were established in our laboratory by continuous exposure to stepwise increases in the concentration of eribulin for more than 6 months, during which time the medium was replaced every 3 days and the cultured cells were subcultured by trypsinization when they reached $70 \%$ confluency. Through this process, we selected several eribulin-resistant clones for each breast cancer cell line, and then used one representative clone in the subsequent experiments. The established eribulin-resistant clones were maintained in the eribulincontaining media throughout the experiments.

Eribulin was purchased from Eisai Co., Ltd. (Tokyo, Japan). Paclitaxel, doxorubicin, and fluorouracil were purchased from Sigma-Aldrich (Saint Louis, MO).

\section{WST assay}

The growth inhibitory effects of eribulin, paclitaxel, doxorubicin, and fluorouracil were measured using a tetrazolium salt-based proliferation assay (WST assay; Wako Chemicals, Osaka, Japan) according to the manufacturer's instructions. Briefly, $4 \times 10^{3}$ cells were cultured in 96-well plates in $100 \mu \mathrm{L}$ of growth medium and incubated for $24 \mathrm{~h}$. Then, $100 \mu \mathrm{L}$ of medium with a graded concentration of eribulin, paclitaxel, doxorubicin, or fluorouracil was added into each well and cultured for $96 \mathrm{~h}$ in the experiment determining the $\mathrm{IC}_{50}$ for the eribulin-resistant cells or $72 \mathrm{~h}$ in the experiments involving transfection with siRNA or plasmid DNA. Then, $10 \mu \mathrm{L}$ of WST-8 solution was added to each well, and the plates were incubated at $37^{\circ} \mathrm{C}$ for another $3 \mathrm{~h}$. The absorbance was measured at 450 and $640 \mathrm{~nm}$ using SoftMax Pro (Molecular Devices, Tokyo, Japan), and the cell viability was determined. Each experiment was independently performed and repeated at least three times.

\section{Total RNA extraction and quantitative real-time RT-PCR}

Total RNA was extracted using an RNeasy Mini kit (Qiagen, Alameda, CA) according to the manufacturer's instructions. TaqMan Gene Expression Assays for $A B C B 1$ (\#Hs00184500_m1), ABCC11 (\#Hs01090768_m1), and $\beta$-actin (\#Hs99999903_m1) were purchased from Applied Biosystems (Carlsbad, CA) and mRNA levels were 
quantified in triplicate using Applied Biosystems 7300 Real-Time PCR system (Carlsbad, CA).

\section{Microarray analysis}

Total RNA from parental MCF7 cells and MCF7/E cells was extracted using an RNeasy Mini kit (Qiagen, Alameda, CA) according to the manufacturer's instructions. Microarray analysis using an Agilent SurePrint G3 Human GE v2 8x60K Microarray (Design ID: 039494) was performed at DNA Chip Research Inc. (Tokyo, Japan).

\section{Western blotting}

Proteins were isolated from cells as previously described and used in western blot analyses $(10 \mu \mathrm{g} /$ lane) [36-37]. The membrane was probed with the following antibodies: anti-ER $\alpha$ antibody (1:200; Santa Cruz Biotechnology, Heidelberg, CA), anti-HER2 antibody(1:1000; Cell Signaling Technology, Danvers, MA), anti-ABCB1 antibody (1:1000; Cell Signaling Technology, Danvers, MA), anti-ABCC11 antibody (1:200; Santa Cruz Biotechnology, Heidelberg, CA), and anti-FLAG antibody (1:500; Sigma, Saint Louis, MO). $\beta$-actin (1:5000; Sigma, Saint Louis, MO) was used as a loading control. Each experiment was repeated independently at least three times and one representative blot was chosen for the figures.

\section{Transfection of siRNA}

ON-TARGET plus siRNA for ABCB1 (L-003868), ABCC11 (L-004344), and the negative control (D-001810) were purchased from GE Healthcare (Buckinghamshire, England).

Transfection of each siRNA (10 nM) was performed using Lipofectamine RNAi-MAX (Thermo Fisher Scientific, Waltham, MA) following the manufacturer's instructions. Twenty-four hours after transfection, the total RNA or protein was extracted and $5 \times 10^{3}$ cells/ well were cultured in 96-well tissue culture plates and incubated for $72 \mathrm{~h}$ after addition of stepwise dilutions of eribulin, paclitaxel, doxorubicin, or fluorouracil. Finally, the absorbance was measured by using the WST solution as described above.

\section{Plasmid construction and transient transfection of expression vectors}

To establish cells expressing Flag-tagged ABCB1, ABCC11, pcDNA3.1-FLAG-ABCB1 and pcDNA3.1-FLAG-ABCC11 were purchased from Genscript (Pistataway, NJ). Then, pcDNA3.1-FLAGABCB1, pcDNA3.1-FLAG-ABCC11, or pcDNA3.1 was transfected into HEK293T cells using FuGENE HD Transfection Reagent (Roche Diagnostics, Basel,
Switzerland) following the manufacturer's protocol. An empty vector was included as a control in all experiments. Twenty-four hours after transfection, proteins were extracted and $5 \times 10^{3}$ cells/well were cultured in 96-well tissue culture plates and incubated for $72 \mathrm{~h}$ after addition of stepwise dilutions of eribulin, paclitaxel, doxorubicin, or fluorouracil. Finally, the absorbance was measured by using the WST solution as described above.

\section{Statistical analysis}

The levels of mRNA expression obtained by realtime RT-PCR were examined by Student's $t$-tests; $P<0.05$ was considered statistically significant (StatFlex ver.6, Artech Co., Ltd., Osaka, Japan).

\section{CONFLICTS OF INTEREST}

The authors declared no conflicts of interest.

\section{GRANT SUPPORT}

This work was supported by a Grant-in-aid for Scientific Research (\#JP25461976) from the Japanese Society for the Promotion of Science.

\section{REFERENCES}

1. Liu J, Towle MJ, Cheng H, Saxton P, Reardon C, Wu J, Murphy EA, Kuznetsov G, Johannes CW, Tremblay MR, Zhao $\mathrm{H}$, Pesant $\mathrm{M}$, Fang $\mathrm{FG}$, et al. In vitro and in vivo anticancer activities of synthetic (-)-laulimalide, a marine natural product microtubule stabilizing agent. Anticancer research. 2007; 27:1509-18.

2. Jordan MA, Kamath K, Manna T, Okouneva T, Miller HP, Davis C, Littlefield BA, Wilson L. The primary antimitotic mechanism of action of the synthetic halichondrin E7389 is suppression of microtubule growth. Molecular cancer therapeutics. 2005; 4:1086-95.

3. Cortes J, O'Shaughnessy J, Loesch D, Blum JL, Vahdat LT, Petrakova K, Chollet P, Manikas A, Dieras V, Delozier T, Vladimirov V, Cardoso F, Koh H, et al. Eribulin monotherapy versus treatment of physician's choice in patients with metastatic breast cancer (EMBRACE): a phase 3 open-label randomised study. Lancet (London, England). 2011; 377:914-23.

4. Klein I, Sarkadi B, Varadi A. An inventory of the human ABC proteins. Biochimica et biophysica acta. 1999; 1461:237-62.

5. Chen Z, Shi T, Zhang L, Zhu P, Deng M, Huang C, Hu T, Jiang L, Li J. Mammalian drug efflux transporters of the ATP binding cassette (ABC) family in multidrug resistance: A review of the past decade. Cancer letters. 2016; 370:153-64. 
6. Sharom FJ. The P-glycoprotein multidrug transporter. Essays in biochemistry. 2011; 50:161-78.

7. Ishii M, Iwahana M, Mitsui I, Minami M, Imagawa S, Tohgo A, Ejima A. Growth inhibitory effect of a new camptothecin analog, DX-8951f, on various drugresistant sublines including BCRP-mediated camptothecin derivative-resistant variants derived from the human lung cancer cell line PC-6. Anti-cancer drugs. 2000; 11:353-62.

8. Oguri T, Fujiwara Y, Isobe T, Katoh O, Watanabe H, Yamakido M. Expression of gamma-glutamylcysteine synthetase (gamma-GCS) and multidrug resistanceassociated protein (MRP), but not human canalicular multispecific organic anion transporter (cMOAT), genes correlates with exposure of human lung cancers to platinum drugs. British journal of cancer. 1998; 77:1089-96.

9. Achiwa H, Oguri T, Sato S, Maeda H, Niimi T, Ueda R. Determinants of sensitivity and resistance to gemcitabine: the roles of human equilibrative nucleoside transporter 1 and deoxycytidine kinase in non-small cell lung cancer. Cancer science. 2004; 95:753-7.

10. Ito K, Oleschuk CJ, Westlake C, Vasa MZ, Deeley RG, Cole SP. Mutation of Trp1254 in the multispecific organic anion transporter, multidrug resistance protein 2 (MRP2) (ABCC2), alters substrate specificity and results in loss of methotrexate transport activity. The Journal of biological chemistry. 2001; 276:38108-14.

11. Borst P, Evers R, Kool M, Wijnholds J. A family of drug transporters: the multidrug resistance-associated proteins. Journal of the National Cancer Institute. 2000; 92:1295-302.

12. Wu $\mathrm{CP}$, Hsieh $\mathrm{CH}, \mathrm{Wu}$ YS. The emergence of drug transporter-mediated multidrug resistance to cancer chemotherapy. Molecular pharmaceutics. 2011; 8:1996-2011.

13. Cole SP, Bhardwaj G, Gerlach JH, Mackie JE, Grant CE, Almquist KC, Stewart AJ, Kurz EU, Duncan AM, Deeley RG. Overexpression of a transporter gene in a multidrugresistant human lung cancer cell line. Science (New York, NY). 1992; 258:1650-4.

14. Guo Y, Kotova E, Chen ZS, Lee K, Hopper-Borge E, Belinsky MG, Kruh GD. MRP8, ATP-binding cassette C11 (ABCC11), is a cyclic nucleotide efflux pump and a resistance factor for fluoropyrimidines 2', 3'-dideoxycytidine and 9'-(2'-phosphonylmethoxyethyl)adenine. The Journal of biological chemistry. 2003; 278:29509-14.

15. Yabuuchi H, Shimizu H, Takayanagi S, Ishikawa $T$. Multiple splicing variants of two new human ATPbinding cassette transporters, $\mathrm{ABCC} 11$ and $\mathrm{ABCC} 12$. Biochemical and biophysical research communications. 2001; 288:933-9.

16. Bera TK, Lee S, Salvatore G, Lee B, Pastan I. MRP8, a new member of $A B C$ transporter superfamily, identified by EST database mining and gene prediction program, is highly expressed in breast cancer. Molecular medicine (Cambridge, Mass). 2001; 7:509-16.
17. Uemura T, Oguri T, Ozasa H, Takakuwa O, Miyazaki M, Maeno K, Sato S, Ueda R. ABCC11/MRP8 confers pemetrexed resistance in lung cancer. Cancer science. 2010; 101:2404-10.

18. Oguri T, Bessho Y, Achiwa H, Ozasa H, Maeno K, Maeda H, Sato S, Ueda R. MRP8/ABCC11 directly confers resistance to 5-fluorouracil. Molecular cancer therapeutics. 2007; 6:122-7.

19. Hooijberg JH, de Vries NA, Kaspers GJ, Pieters R, Jansen G, Peters GJ. Multidrug resistance proteins and folate supplementation: therapeutic implications for antifolates and other classes of drugs in cancer treatment. Cancer chemotherapy and pharmacology. 2006; 58:1-12.

20. Tammur J, Prades C, Arnould I, Rzhetsky A, Hutchinson A, Adachi M, Schuetz JD, Swoboda KJ, Ptacek LJ, Rosier M, Dean M, Allikmets R. Two new genes from the human ATP-binding cassette transporter superfamily, ABCC11 and $\mathrm{ABCC} 12$, tandemly duplicated on chromosome $16 \mathrm{q} 12$. Gene. 2001; 273:89-96.

21. Chen ZS, Guo Y, Belinsky MG, Kotova E, Kruh GD. Transport of bile acids, sulfated steroids, estradiol 17-betaD-glucuronide, and leukotriene $\mathrm{C} 4$ by human multidrug resistance protein 8 (ABCC11). Molecular pharmacology. 2005; 67:545-57.

22. Laughney AM, Kim E, Sprachman MM, Miller MA, Kohler RH, Yang KS, Orth JD, Mitchison TJ, Weissleder R. Singlecell pharmacokinetic imaging reveals a therapeutic strategy to overcome drug resistance to the microtubule inhibitor eribulin. Science translational medicine. 2014; 6:261 ra152.

23. Haimeur A, Conseil G, Deeley RG, Cole SP. The MRPrelated and BCRP/ABCG2 multidrug resistance proteins: biology, substrate specificity and regulation. Current drug metabolism. 2004; 5:21-53.

24. Juliano RL, Ling V. A surface glycoprotein modulating drug permeability in Chinese hamster ovary cell mutants. Biochimica et biophysica acta. 1976; 455:152-62.

25. Schinkel AH, Jonker JW. Mammalian drug efflux transporters of the ATP binding cassette (ABC) family: an overview. Advanced drug delivery reviews. 2003; 55:3-29.

26. Matheny CJ, Lamb MW, Brouwer KR, Pollack GM. Pharmacokinetic and pharmacodynamic implications of P-glycoprotein modulation. Pharmacotherapy. 2001; 21:778-96.

27. Morrissey KM, Wen CC, Johns SJ, Zhang L, Huang SM, Giacomini KM. The UCSF-FDA TransPortal: a public drug transporter database. Clinical pharmacology and therapeutics. 2012; 92:545-6.

28. Sharom FJ. ABC multidrug transporters: structure, function and role in chemoresistance. Pharmacogenomics. 2008; 9:105-27.

29. Kim RB. Drugs as P-glycoprotein substrates, inhibitors, and inducers. Drug metabolism reviews. 2002; 34:47-54.

30. Choudhuri S, Klaassen CD. Structure, function, expression, genomic organization, and single nucleotide polymorphisms 
of human ABCB1 (MDR1), ABCC (MRP), and ABCG2 (BCRP) efflux transporters. International journal of toxicology. 2006; 25:231-59.

31. Yoshiura K, Kinoshita A, Ishida T, Ninokata A, Ishikawa T, Kaname T, Bannai M, Tokunaga K, Sonoda S, Komaki R, Ihara M, Saenko VA, Alipov GK, et al. A SNP in the ABCC11 gene is the determinant of human earwax type. Nature genetics. 2006; 38:324-30.

32. Inoue $Y$, Mori T, Toyoda $Y$, Sakurai A, Ishikawa T, Mitani Y, Hayashizaki Y, Yoshimura Y, Kurahashi H, Sakai Y. Correlation of axillary osmidrosis to a SNP in the ABCC11 gene determined by the Smart Amplification Process (SmartAmp) method. Journal of plastic, reconstructive \& aesthetic surgery: JPRAS. 2010; 63:1369-74.

33. Toyoda Y, Sakurai A, Mitani Y, Nakashima M, Yoshiura K, Nakagawa H, Sakai Y, Ota I, Lezhava A, Hayashizaki Y, Niikawa N, Ishikawa T. Earwax, osmidrosis, and breast cancer: why does one $\mathrm{SNP}(538 \mathrm{G}>\mathrm{A})$ in the human $\mathrm{ABC}$ transporter $\mathrm{ABCC} 11$ gene determine earwax type? FASEB journal. 2009; 23:2001-13.

34. Kruh GD, Belinsky MG, Gallo JM, Lee K. Physiological and pharmacological functions of Mrp2, Mrp3 and Mrp4 as determined from recent studies on gene-disrupted mice. Cancer metastasis reviews. 2007; 26:5-14.

35. Bortfeld M, Rius M, Konig J, Herold-Mende C, Nies AT, Keppler D. Human multidrug resistance protein 8 (MRP8/ ABCC11), an apical efflux pump for steroid sulfates, is an axonal protein of the CNS and peripheral nervous system. Neuroscience. 2006; 137:1247-57.

36. Trock BJ, Leonessa F, Clarke R. Multidrug resistance in breast cancer: a meta-analysis of MDR1/gp170 expression and its possible functional significance. Journal of the National Cancer Institute. 1997; 89:917-31.

37. Fujita T, Ito K, Izumi H, Kimura M, Sano M, Nakagomi H, Maeno K, Hama Y, Shingu K, Tsuchiya S, Kohno K, Fujimori M. Increased nuclear localization of transcription factor Y-box binding protein 1 accompanied by up-regulation of P-glycoprotein in breast cancer pretreated with paclitaxel. Clinical cancer research. 2005; 11:8837-44.
38. Ito K, Fujimori M, Nakata S, Hama Y, Shingu K, Kobayashi S, Tsuchiya S, Kohno K, Kuwano M, Amano J. Clinical significance of the increased multidrug resistance-associated protein (MRP) gene expression in patients with primary breast cancer. Oncology research. 1998; 10:99-109.

39. Ota I, Sakurai A, Toyoda Y, Morita S, Sasaki T, Chishima T, Yamakado M, Kawai Y, Ishidao T, Lezhava A, Yoshiura K, Togo S, Hayashizaki Y, et al. Association between breast cancer risk and the wild-type allele of human ABC transporter ABCC11. Anticancer research. 2010; 30:5189-94.

40. Yamada A, Ishikawa T, Ota I, Kimura M, Shimizu D, Tanabe M, Chishima T, Sasaki T, Ichikawa Y, Morita S, Yoshiura K, Takabe K, Endo I. High expression of ATPbinding cassette transporter ABCC11 in breast tumors is associated with aggressive subtypes and low diseasefree survival. Breast cancer research and treatment. 2013; 137:773-82.

41. Coates AS, Winer EP, Goldhirsch A, Gelber RD, Gnant M, Piccart-Gebhart M, Thurlimann B, Senn HJ. -Tailoring therapies-improving the management of early breast cancer: St Gallen International Expert Consensus on the Primary Therapy of Early Breast Cancer 2015. Annals of oncology. 2015; 26:1533-46.

42. Honorat M, Mesnier A, Vendrell J, Guitton J, Bieche I, Lidereau R, Kruh GD, Dumontet C, Cohen P, Payen L. $\mathrm{ABCC} 11$ expression is regulated by estrogen in MCF7 cells, correlated with estrogen receptor alpha expression in postmenopausal breast tumors and overexpressed in tamoxifen-resistant breast cancer cells. Endocrine-related cancer. 2008; 15:125-38.

43. Shi JF, Yang N, Ding HJ, Zhang JX, Hu ML, Leng Y, Han X, Sun YJ. ERalpha directly activated the MDR1 transcription to increase paclitaxel-resistance of ERalpha-positive breast cancer cells in vitro and in vivo. The international journal of biochemistry \& cell biology. 2014; 53:35-45.

44. Giordano SH, Buzdar AU, Smith TL, Kau SW, Yang Y, Hortobagyi GN. Is breast cancer survival improving? Cancer. 2004; 100:44-52. 